\title{
Evaluation of the Adhesion between Overlays and Substrates in Concrete Floors: Literature Survey, Recent Non-Destructive and Semi-Destructive Testing Methods, and Research Gaps
}

\section{Jacek Szymanowski}

Wroclaw University of Science and Technology, Faculty of Civil Engineering Wybrzeże Wyspiańskiego 27, 50-370 Wroclaw, Poland; jacek.szymanowski@pwr.edu.pl

Received: 13 August 2019; Accepted: 4 September 2019; Published: 11 September 2019

\begin{abstract}
Non-destructive testing (NDT) and semi-destructive testing (SDT) have recently been more frequently used for the evaluation and condition assessment of concrete floors in various types of buildings. The subject of the article is to briefly introduce the reader to the problem of adhesion between overlays and substrates in concrete floors and to illustrate the current state of knowledge on the subject. The aim of this paper was to briefly describe the recently used non-destructive and semi-destructive testing methods and the parameters useful for characterizing the adhesion between overlays and substrates in concrete floors, as well as the methods useful to characterize the functional properties of the overlays. A recent literature survey, related to the adhesion between the overlays and substrates in concrete floors, is thus shown. Special emphasis was placed on the critical review of the current research results. Based on the analysis of the literature review, research gaps have been presented in order to highlight future research directions.
\end{abstract}

Keywords: non-destructive testing; semi-destructive testing; cement mortar; pull-off adhesion; overlay; substrate; functional properties; abrasion resistance; subsurface tensile strength; hardness

\section{Introduction}

Non-destructive testing (NDT) and semi-destructive testing (SDT) have recently been more frequently used for the evaluation and condition assessment of concrete floors in various types of buildings [1]. Nowadays, concrete floors are commonly used in civil engineering [2-4], and they are made of overlays that are placed on the substrate [5]. The most important properties of overlays are associated with their proper adhesion to the substrate, as well as their corresponding functional properties, such as abrasion resistance, subsurface tensile strength or hardness [6].

A floor is a horizontal interior element in a building, normally consisting of an overlay (flooring) applied on the substrate. The substrate is placed on the base. The load, which impacts on the overlay, is transferred to the base. The substrate is the structural support of the floor and transfers the load to the ground directly or indirectly through other elements of the building (e.g., a slab floor and walls) [7].

It should be added that an overlay has to be adapted to functional requirements, e.g., by applying a finishing layer on it [8]. Nowadays, floors with concrete layers are generally being used in most residential building objects. They are used, among others, in residential and public buildings, warehouses, production buildings, and one and multilevel car parks.

A concrete floor consists of an overlay that is usually made of cement mortar and substrate (Figure 1). The substrate is usually made of concrete. Between the overlay and the substrate, a bonding agent can also be applied. The interphase zone between the overlay and substrate can be set apart, 
which according to literature can be divided into the near-surface zone of the overlay mortar (NSZ-OM) and the near-surface zone of the concrete substrate (NSZ-CS). Other names are shown in Figure 1.

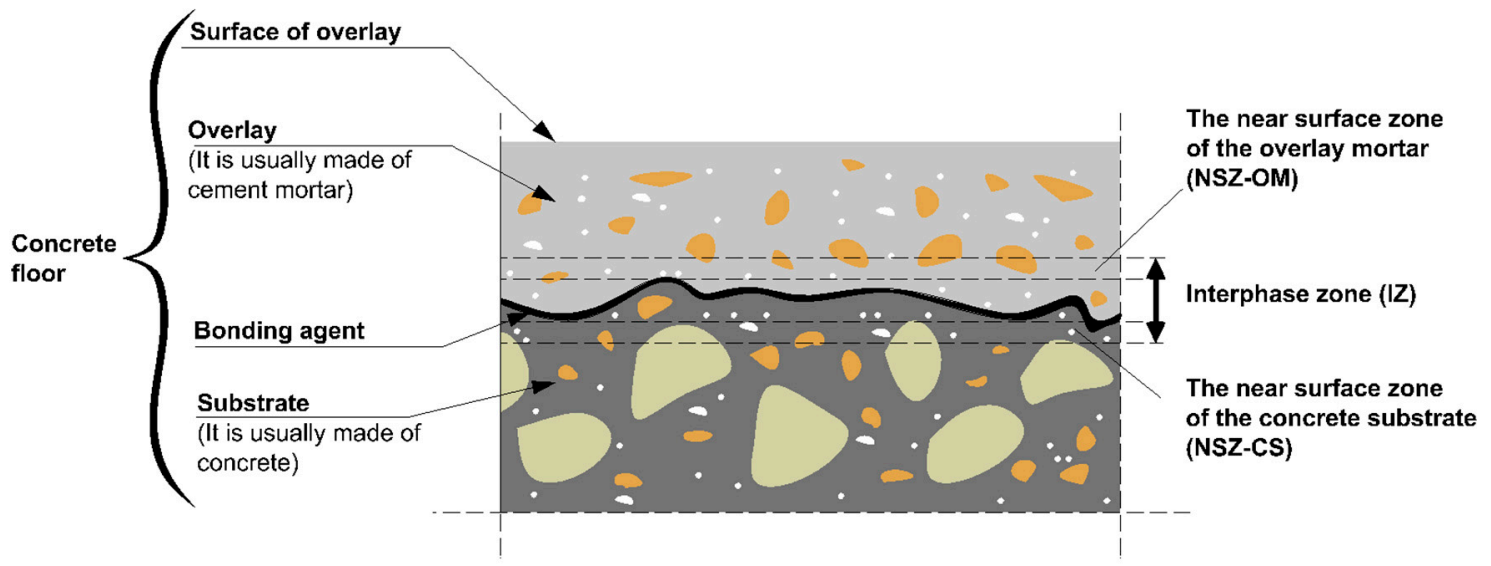

Figure 1. Explanation of basic definitions used in the article.

These floors are popular in residential, civil, and industrial buildings, e.g., in indoor car parks [9]. As is shown in Figure 2, floors, depending on the used material, can be divided into: mineral floors, floors of epoxy resins, bituminous, artificial paneling, ceramic, stoned, and steel. However, floorings made of cement composites and concrete hardening are the most often used.

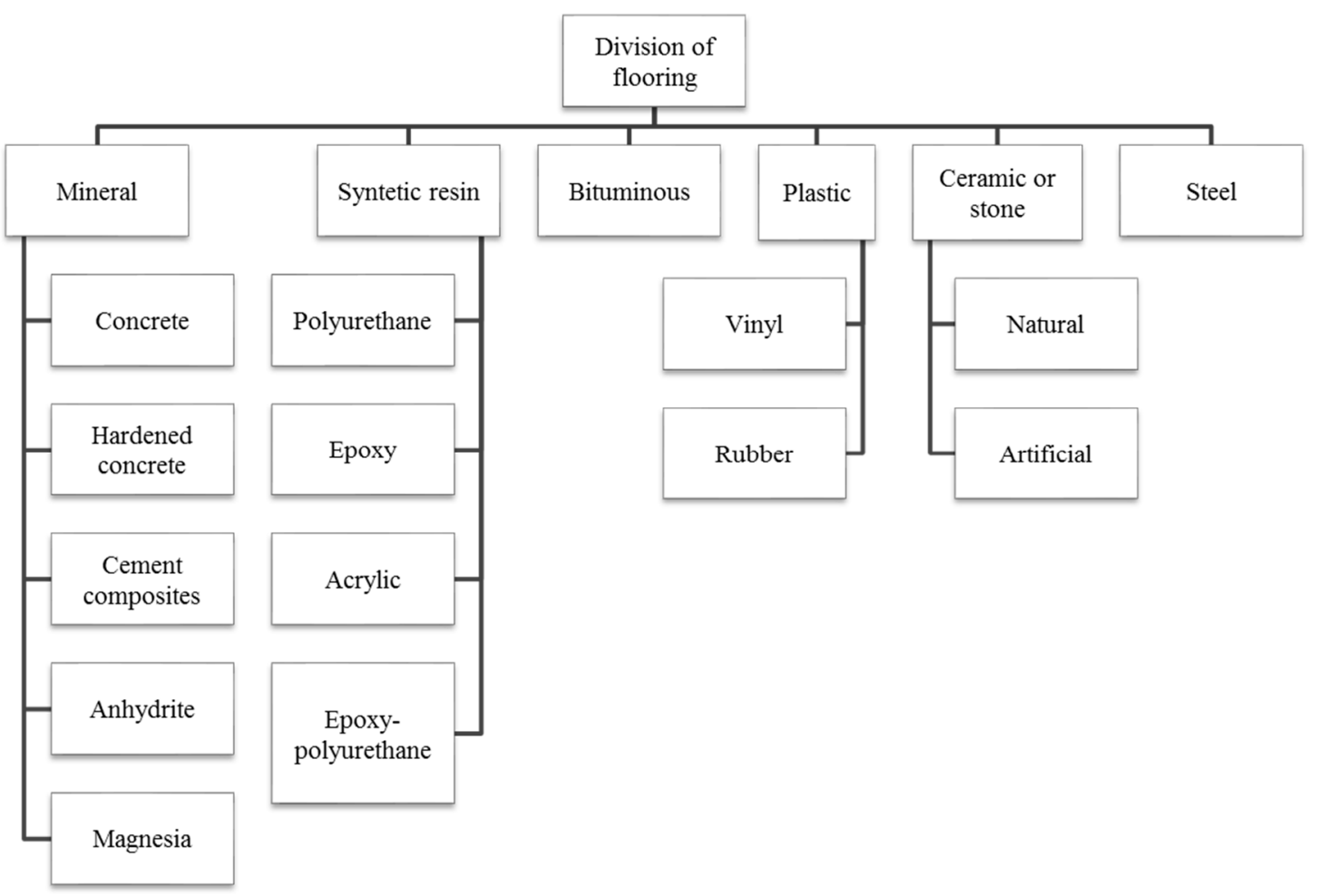

Figure 2. Types of floorings, depending on the material of which they are made (based on Reference [10]).

The aim of the article was to introduce non-destructive and semi-destructive testing methods, the parameters connected with the issue of adhesion between overlays and substrates, and also the functional parameters of the overlay in concrete floors. The literature survey and review of current research results are shown. The research gaps are also presented in order to highlight future research directions. 


\section{Overview of Recent Non-Destructive and Semi-Destructive Testing Methods Used to Assess the Adhesion between Overlays and Substrates in Concrete Floors}

A proper method should be chosen, depending on the requirements concerning the carried-out repair [11]. The methods of testing the bond between a concrete substrate and an overlay can be divided, depending on the direction of load application, into three groups [12]. Tests to determine the bond between the concrete substrate and the overlay are shown in Figure 3.

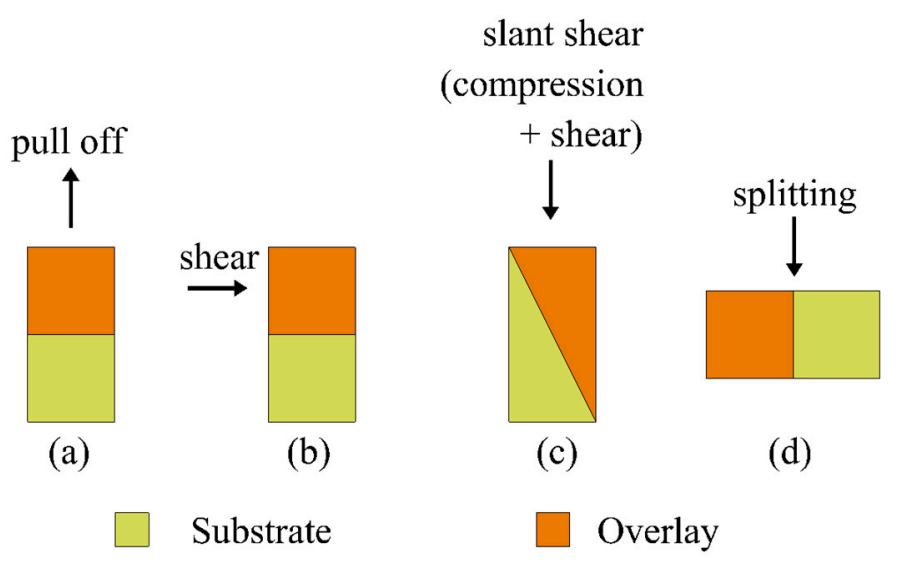

Figure 3. Tests to determine the bond between the concrete substrate and the overlay: (a) pull-off, (b) shear, (c) slant shear, (d) splitting.

The first group of methods assumes testing under tension stress. They are the pull-off method (Figure 3a) and the splitting prism method (Figure 3d). The splitting method is based on applying a longitudinal compressive load on the interface of the concrete substrate and the overlay. The second group of methods assumes testing under shear stress. The direct shear method is shown in Figure $3 \mathrm{~b}$. The third group assumes both compression and shear stress working together. The slant shear method is shown in Figure 3c. In practice, the pull-off method [13], in which adhesion is assessed by measuring the strength of pulling off the repaired layer of the substrate, is most often used [14]. The scheme of the pull-off and the view of the used equipment is shown in Figure 4. In this method, the measurement of the pull-off adhesion $f_{b}$ between the repaired layer and the substrate is carried out on the basis of the measurement of the value of the pulling off strength of the steel disk with a digital or indicating manometer. Drills in the overlay of a diameter of $D_{f}=50 \mathrm{~mm}$ and a depth that is shown in Figure 4 are performed in this method. Then, steel discs are glued to the overlay and pulled off the substrate surface at an angle of 90 degrees. The increase of the value of pull off stress should be equal to $0.05 \mathrm{MPa} / \mathrm{s}$. The pull-off method is quantitative because it enables the pull-off value $f_{b}$ to be determined as follows (1):

$$
f_{b}=\frac{4 F_{b}}{\pi D_{f}^{2}}
$$

where:

$$
\begin{aligned}
& F_{b} \text { - the failure load }(\mathrm{N}) \\
& D_{f} \text { - the diameter of drilling core }(\mathrm{m})
\end{aligned}
$$

Figure 4 shows the scheme of the pull-off method and the view of the testing device. 
a)

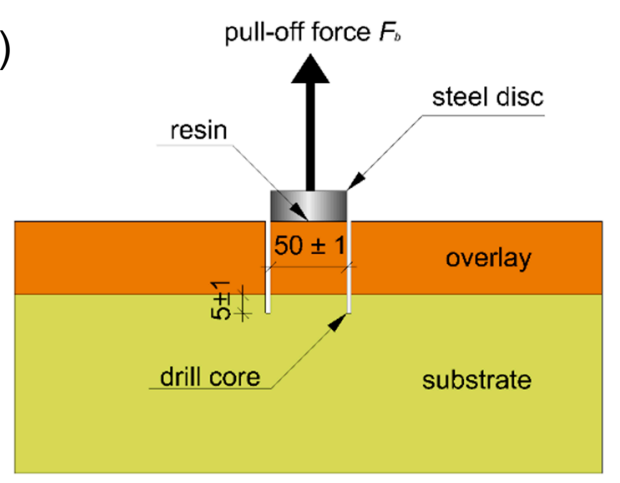

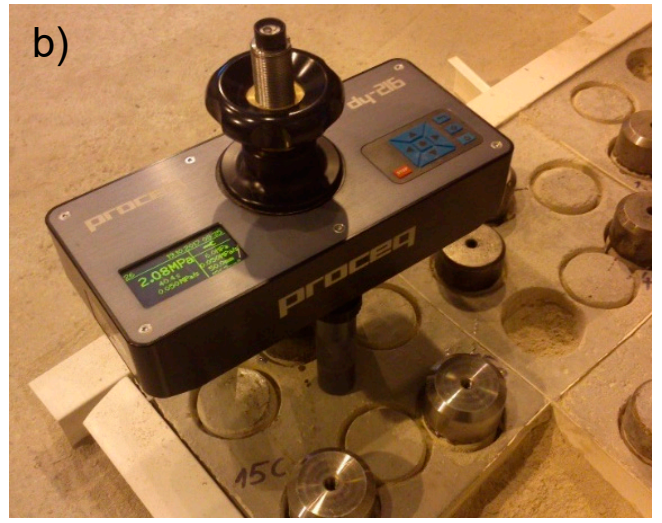

Figure 4. The scheme of the pull-off method (a) and a view of the testing device (b).

When taking into consideration the durability of the overlay, an appropriate pull-off adhesion $f_{b}$ between the overlay and the substrate of $1.5 \mathrm{MPa}$ is demanded for repaired overlays and $0.5 \mathrm{MPa}$ for newly built overlays.

The durability of a floor, especially when it is heavily loaded because of driving cars or loading trucks, depends significantly on the proper bonding between the overlay and the substrate [15]. The technical measure of the bonding is the value of pull-off adhesion $f_{b}$, which is determined with the semi-destructive pull-off method. According to requirements for floors included in Reference [16], it is demanded that the minimum value of pull-off adhesion $f_{b}$ between the overlay and the substrate is equal to no less than $0.5 \mathrm{MPa}$. If the value of adhesion is equal to 0 , it would mean that so-called delamination has appeared, i.e., a complete lack of adhesion.

\section{Overview of Recent Non-Destructive and Semi-Destructive Testing Methods Used to Assess the Functional Properties of Overlays}

\subsection{Abrasion Resistance—Boehme Test}

The basis of the method is to subject the examined sample, with section dimensions of $71 \times 71 \mathrm{~mm}$, to 16 cycles of abrasion on a rotating abrasion wheel (Boehme wheel) [17]. Each cycle consists of even spilling of $20 \mathrm{~g}$ of carborundum abrasive sand on the Boehme wheel, attaching the sample to the handle, loading it with a force of $294+-3 \mathrm{~N}$ and then subjecting it to 22 rotations of the disc in each cycle. After each cycle, the sample should be turned at 90 degrees, and after every four cycles, it should be weighed. Then, abrasion, as the mass decrease or volume decrease of the sample after 16 cycles, should be calculated as follows (2):

$$
\Delta V=\frac{\Delta m}{\rho_{R}}
$$

$\Delta V$-decrease of volume after 16 cycles (in cubic millimeters)

$\Delta m$-decrease of mass after 16 cycles (in grams)

$\rho_{R}$ - the density of the examined sample, or in the case of multilayer samples, abrasion layer density (in grams per cubic millimeters)

Figure 5 shows the scheme and view of the Boehme test device. 

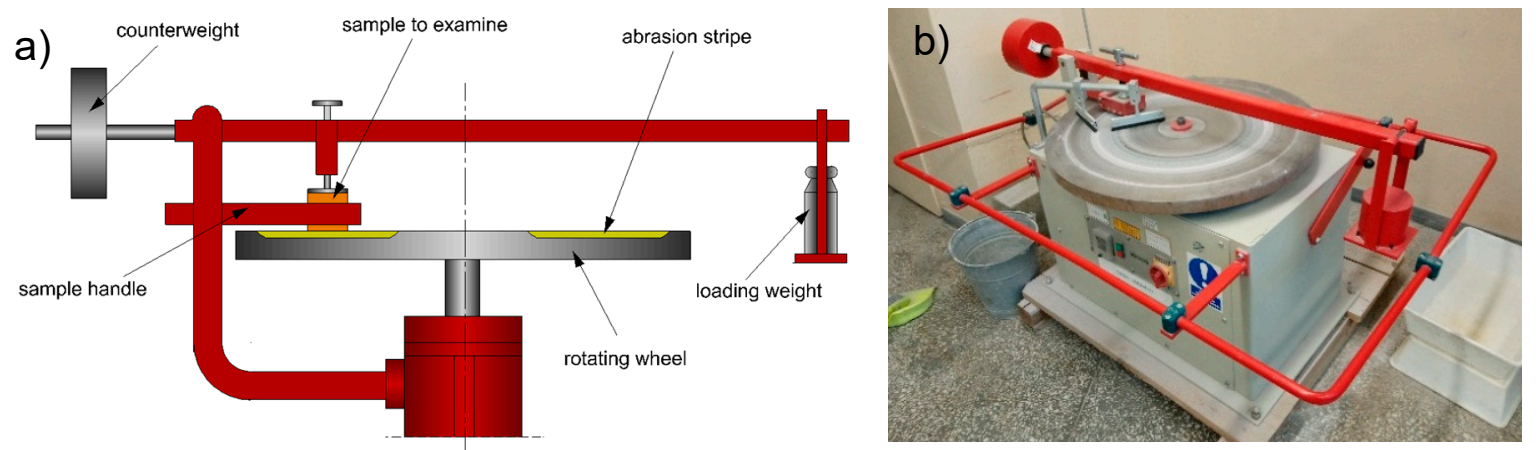

Figure 5. The scheme (a) and view (b) of the Boehme test device.

\subsection{Subsurface Tensile Strength-Pull-Off Test}

The pull-off method is also used to determine the subsurface tensile strength [18]. In order to assess the strength, drilling in the overlay of $50 \mathrm{~mm}$ diameter and to a depth of around $15 \mathrm{~mm}$ is carried out. Then, the steel discs are glued to the surface of the overlay and the pulling off force is applied. The subsurface tensile strength can be calculated as below:

$$
f_{h s}=\frac{4 F_{b}}{\pi D_{f}^{2}}
$$

where:

$$
\begin{aligned}
& F_{b} \text { - the failure load }(\mathrm{N}) \\
& D_{f} \text { - the diameter of drilling core }(\mathrm{m})
\end{aligned}
$$

Figure 6 shows the scheme of the pull-off method according to subsurface tensile strength testing.

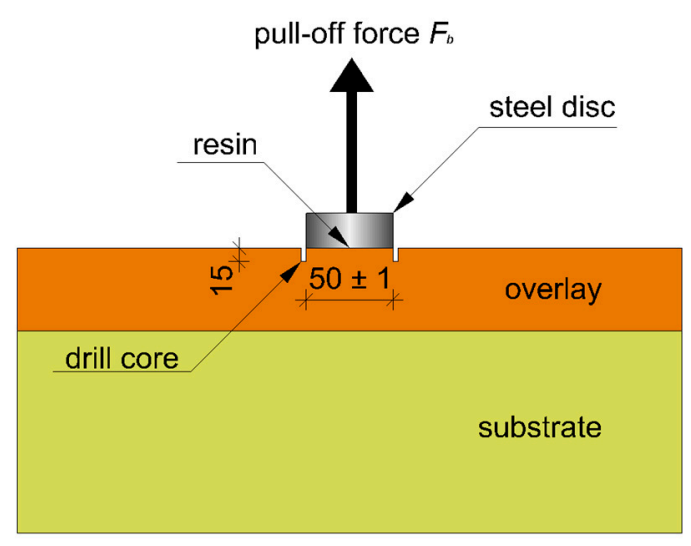

Figure 6. The scheme of the pull-off method according to subsurface tensile strength testing.

\subsection{Surface Hardness-The Sclerometric Method}

The scheme of the sclerometric method, together with the view of the testing device and the relation between the compressive strength and rebound number are presented in Figure 7. 

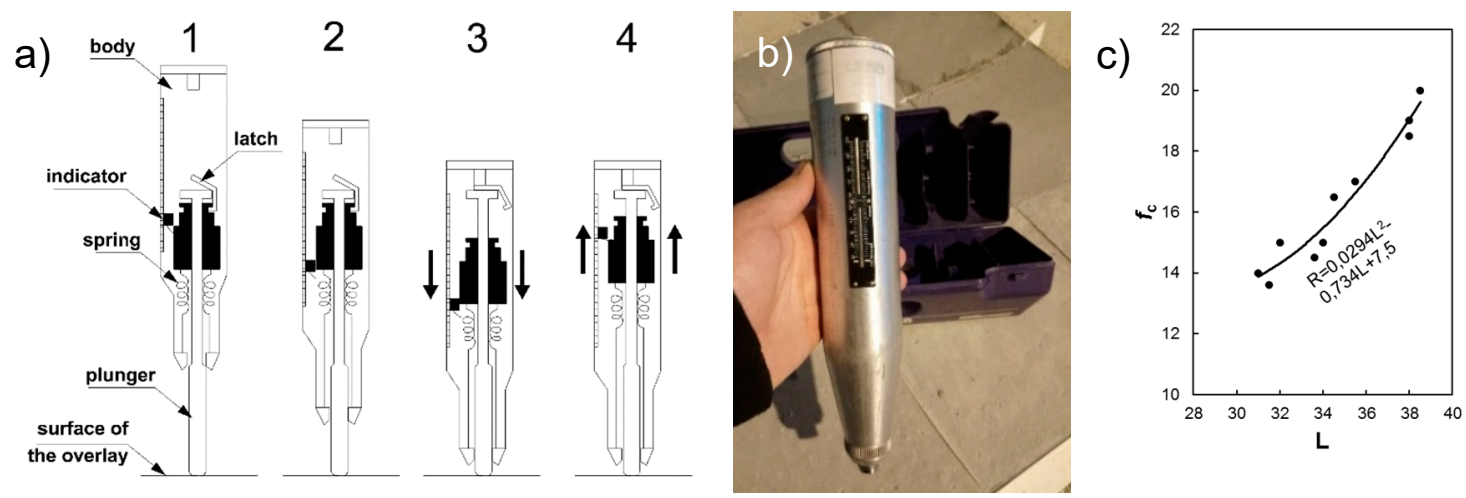

Figure 7. The scheme of the sclerometric method (a), the view of the testing device (b), and the typical relation (c) between the rebound number and compressive strength (based on References $[19,20]$ ).

The relation between the hardness of concrete and the rebound number is the basis of this method [19-22]. Figure 7 shows the view of the hammer (also named Schmidt hammer) and the scheme of the sclerometric method. The main parts of the hammer are a plunger, spring, indicator, latch, and body. Position 1 in the scheme shows the hammer in the first part of the test. The plunger is applied in the testing place and the latch holding the hammer mass is locked. Position 2 in the scheme shows the hammer during the test when the body is pushing against the concrete surface. The spring tension is increasing, and the latch is still locked. Position 3 in the scheme shows the moment in the test when the latch is released, and the hammer mass is pushed against the plunger tip by the spring. The last position in the scheme (number 4) shows the moment when the hammer mass moves the indicator after impacting the plunger tip and rebounding. Then, the rebound number is read from the scale. The rebound number can also be used to estimate compressive strength or flexural strength. For this purpose, concrete has to be tested with the hammer. The compressive strength of control samples should then be determined (the control samples can be taken from the existing structure or prepared based on the same mix composition). Next, the relation between the rebound number and compressive strength is created (on the right side in Figure 7) and correlation analysis should be carried out using the least squares method (the hypothetical regression curve based on previous research can be taken into consideration for some conditions). However, it must also be stated that a large number of measuring points is necessary to obtain statistically reliable results. Despite the possibilities that the rebound hammer provides, there are factors affecting the results. The following limitations should be taken into consideration during the analysis: age of test specimens; surface and internal moisture conditions; the size, shape, and rigidity of the specimens; smoothness of test surface; type of coarse aggregate; type of cement; and carbonation of the concrete surface [23-27]. The hammer has recently also been used together with other non-destructive and semi-destructive testing methods to assess the compressive strength of concrete [27-32].

\section{Overview of Recent Activities Used to Improve the Pull-Off Adhesion of Overlay with Substrate}

The following activities to improve the pull-off adhesion $f_{b}$ of overlay with substrate are used:

- Mechanical treatment of the surface of the substrate;

- Surface texturing;

- Removal of cement laitance from the concrete substrate surface;

- Surface exposure of the aggregate;

- Surface strengthening of the concrete substrate with bonding agents;

- Modifications of the material of the overlay. 


\subsection{Mechanical Treatment of the Surface of Substrate}

In recent years, a great deal of research has been carried out according to the influence of the morphology of a concrete surface to its bonding with the overlay [33-37]. The methods of evaluating a concrete surface were performed by, among others, Santos and Julio [38], Mathia et al. [39], and Garbacz et al. [40]. At present, the scanning electron microscopy (SEM) method is increasingly used for this purpose [41-43]. The principle of this method is as follows: An electron gun generates the electron beam. When the electrons enter the concrete surface, low energy secondary electrons are generated. The intensity of the secondary electrons depends on the concrete surface morphology and, therefore, an SEM image of the surface is created as a function between the intensity of secondary electrons and the position of the scanning electron beam. This method provides many advantages, such as high magnification and resolution of obtained images at nanoscale, or the possibility to determine the chemical composition of studied samples. Generally, the available methods of treatment can be divided into three main groups: cleaning and non-invasive removal methods, coarsening methods, and invasive removal methods. Each type of the above-mentioned groups contains methods that differ with the mechanism of treatment, and this is why it has particular applications. The exemplary views of the concrete substrate surface after treatment are shown in Figure 8.
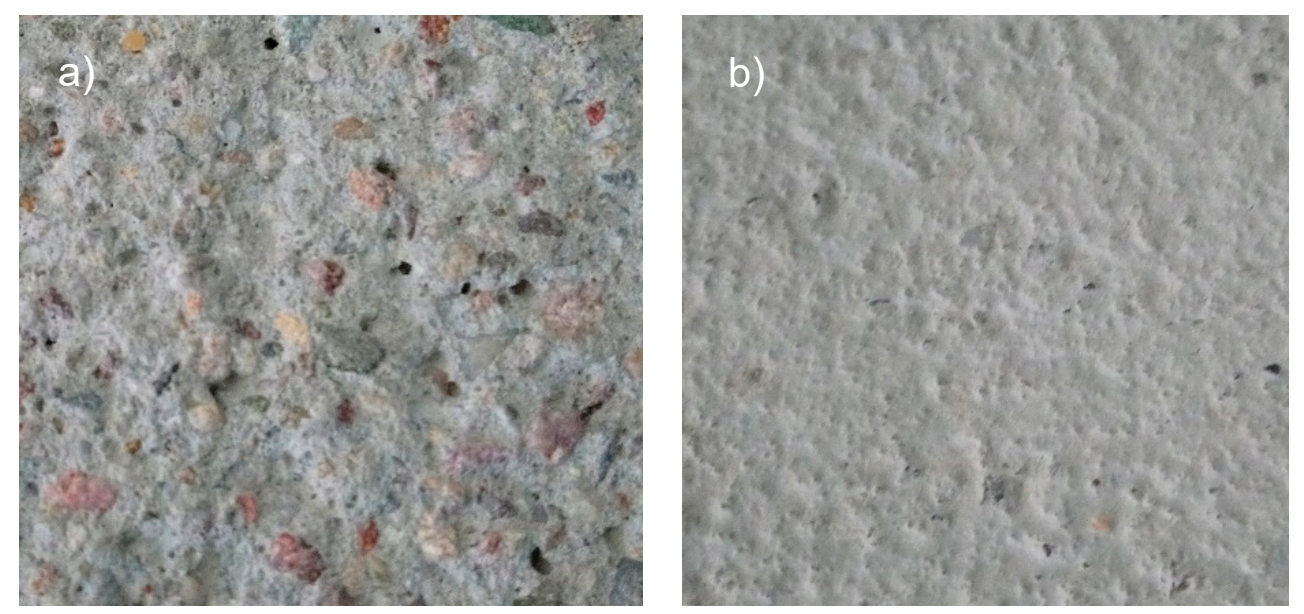

Figure 8. The exemplary view of the concrete substrate surface after shot-blasting (a) and patch grabbing (b).

Figure 9 shows the division of several concrete treatment methods, depending on their type.

From the methods presented in Figure 9, the cleaning and non-invasive types of methods contain grinding and low-pressure cleaning. Attrition is the mechanism of grinding. This method reveals the fine grain aggregate due to the removal of cement laitance, loose fragments, and other impurities. Water erosion is the mechanism of treatment of low-pressure cleaning. It enables the removal of water-soluble contamination and brittle cementitious material from the surface. The second group (coarsening) contains milling, scabbling, and shot-blasting/sand-blasting. Hitting is the method of treatment for milling. Milling allows for the obtention of a regular profile of parallel grooves on the surface, the removal of the whole cement laitance, and the levelling of large irregularities (up to $20 \mathrm{~mm}$ ). Scabbing is based on using pneumatic devices such as hammers, piston-mounted bits, etc. It removes the material of the overlay near to its surface (up to $6 \mathrm{~mm}$ depending on the used device). The shot-blasting and the sand-blasting mechanism of treatment is spraying. These methods remove brittle material, cement laitance, and dirt from the overlay surface, and reveal the coarse aggregate. The profile of the surface after these treatments depends on the granulation and abrasiveness of the surface material of the overlay. The invasive removal methods contain flame treatment and hydrodemolition (also named water jetting or water-blasting). Flame treatment uses pressure expansion by steam and removes fragments of concrete (a maximum of $6 \mathrm{~mm}$ ). In turn, 
hydrodemolition enables the removal of concrete fragments of up to $19 \mathrm{~mm}$, depending on the water pressure. Recent research has shown that shot-blasting of a concrete substrate surface improves the level of adhesion of the cement mortar overlay with the substrate [44-48]. Figure 10 shows the relation between the pull-off adhesion $f_{b}$ between the overlay and the existing concrete substrate and the method of treatment of the concrete substrate surface.

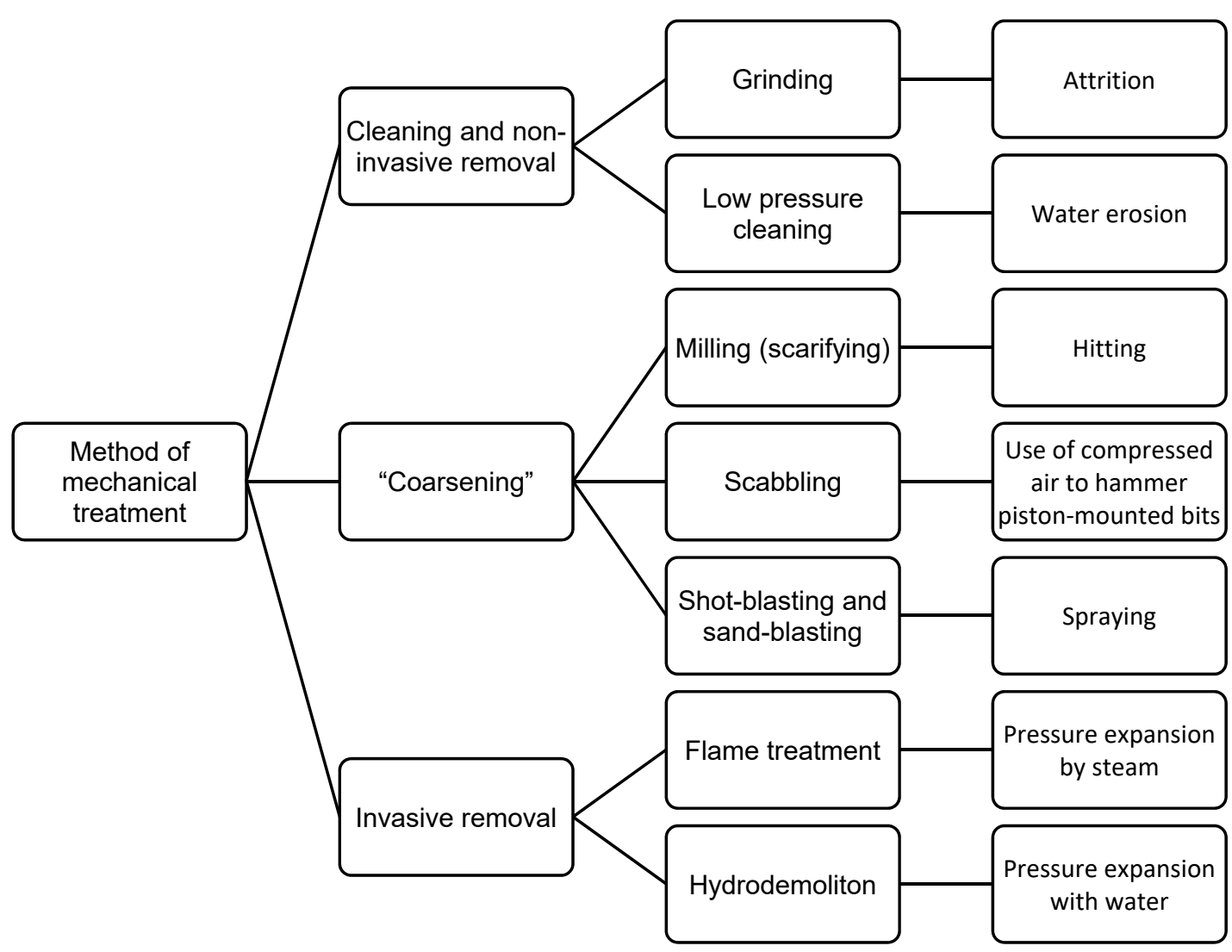

Figure 9. Division of concrete treatment methods (based on Reference [5]).

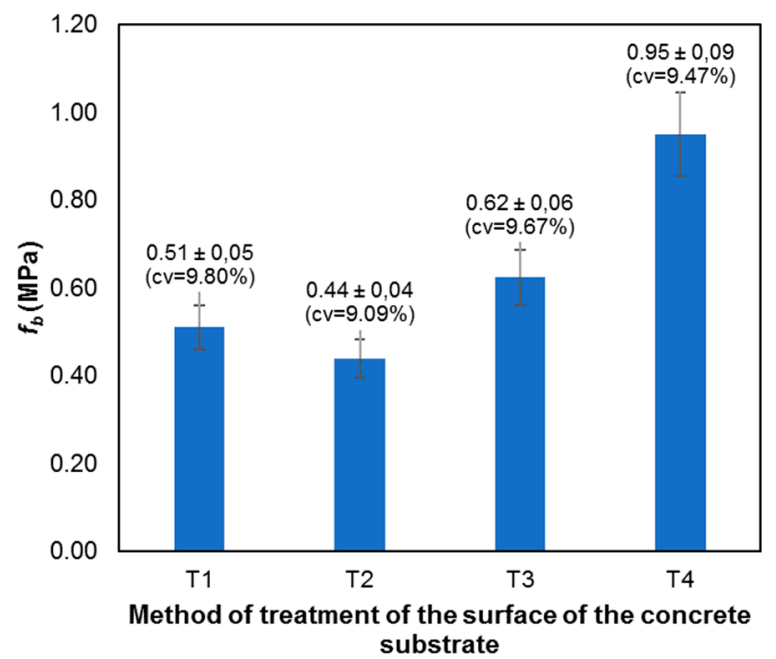

Figure 10. The test results of the pull-off adhesion $f_{b}$ between the overlay and the existing concrete substrate using the pull-off method (based on the results presented in Reference [44]). Methods of surface treatment: T1 - patch grabbed (raw) surface, T2 - formed after contact with formwork (as cast) surface, T3-mechanically grinded surface, T4—shot-blasted surface. 
Figure 10 shows that only an increase of the effective relative surface area (of the substrate) does not cause the considerable increase of adhesion that is noticeable in the case of the raw surface and as cast surface (T1 and T2). Moreover, only exposure of the aggregate (on substrate surface) does not cause the visible increase of the level of adhesion that is noticeable in the case of the mechanically grinded surface T3. Only simultaneous increasing of the effective relative surface area and exposure of the aggregate considerably increases the level of adhesion, as was the case for the shot-blasted surface T4.

However, Franck and De Belie [49], in order to determine the influence of the way of treating the concrete surface on the value of $R a$ and $R q$ parameters (Figure 11), subjected the surface of a concrete floor to research with the jointless method laser beam. The figure shows that the values of arithmetical mean height $(\mathrm{Ra})$ and root mean square deviation $(R \mathrm{q})$ of the concrete surface subjected to sand-blasting are about eight times higher than for the raw surface, and about two times higher than for the wire brushed surface.

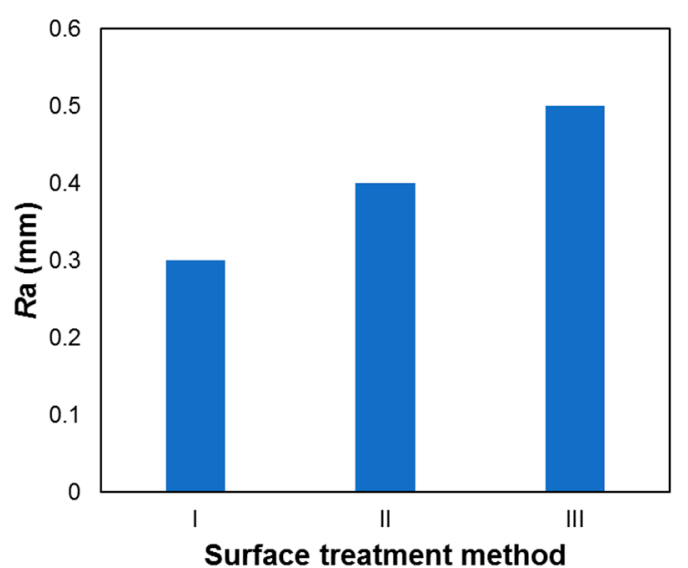

(a)

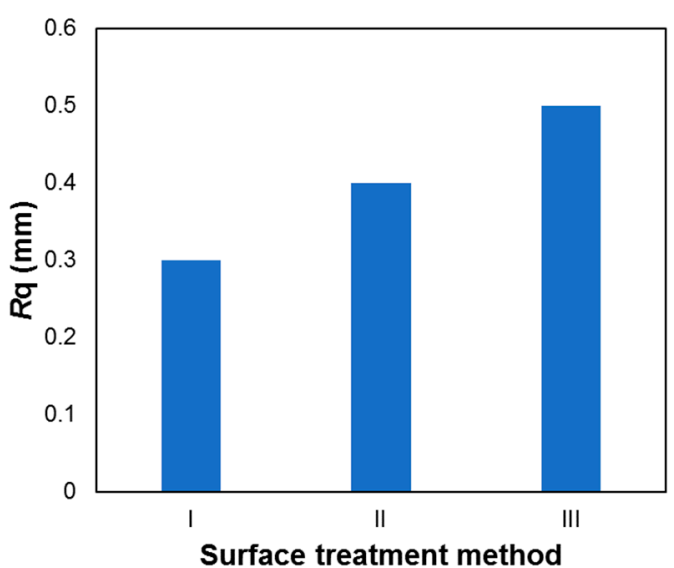

(b)

Figure 11. The effect of the surface treatment method on the value of: (a) arithmetical mean height (Ra) of the concrete surface, $(\mathbf{b})$ root mean square deviation $(R q)$ of the concrete surface. The surface treatment methods were marked as follows: I-as cast surface, II—-wire-brushed surface, III—-sand-blasted surface (based on the results presented in Reference [49]).

The research shows that together with increasing the fraction of pores $\Phi$ and the number of pores within the interphase zone, the value $f_{b}$ decreases. In the case of substrate, the relation is the opposite-together with increasing the fraction of pores $\Phi$ and the number of pores in the near surface zone of the concrete substrate (NSZ-CS), the value $f_{b}$ increases [50-54]. The relations between the total fraction of pores and the pull-off adhesion $f_{b}$ are shown in Figure 12a. In turn, the relations between the number of pores and the pull-off adhesion $f_{b}$ are shown in Figure $12 \mathrm{~b}$. 
a)

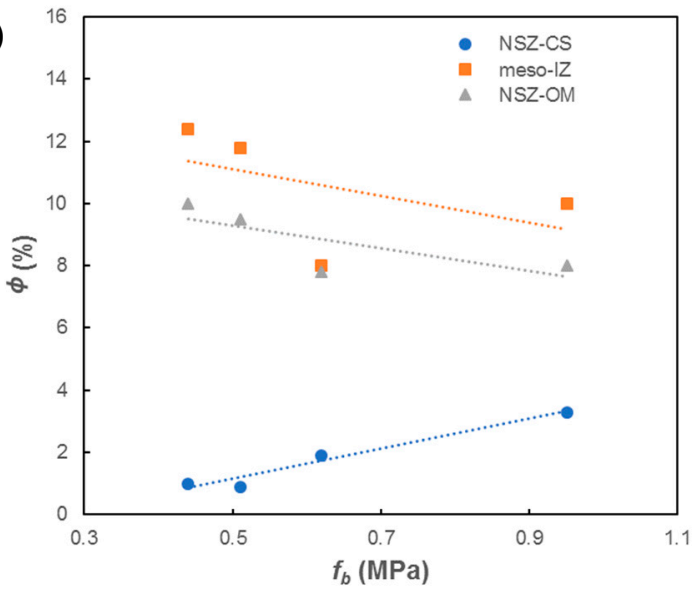

b)

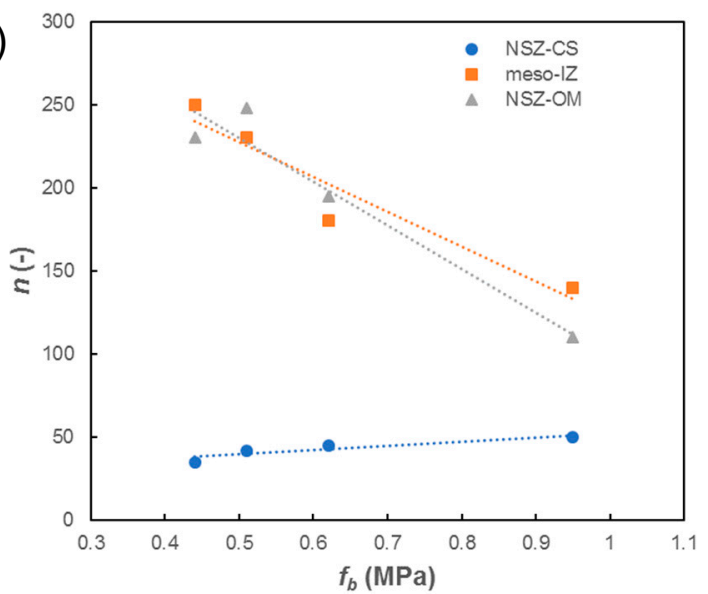

Figure 12. Relation of the pull-off adhesion $f_{b}$ of the overlay with the substrate with regard to fraction of pores $\Phi(\mathbf{a})$ and number of pores (b): IZ-interphase zone, NSZ-CS-the near surface zone of the concrete substrate, NSZ-OM-the near surface zone of the mortar overlay (based on the results presented in Reference [50]).

\subsection{Texturing of the Surface of the Concrete Substrate}

The second way to improve the pull-off adhesion $f_{b}$ between the concrete substrate and the overlay is by texturing the substrate surface. The division of the texturing method is presented in Figure 13.

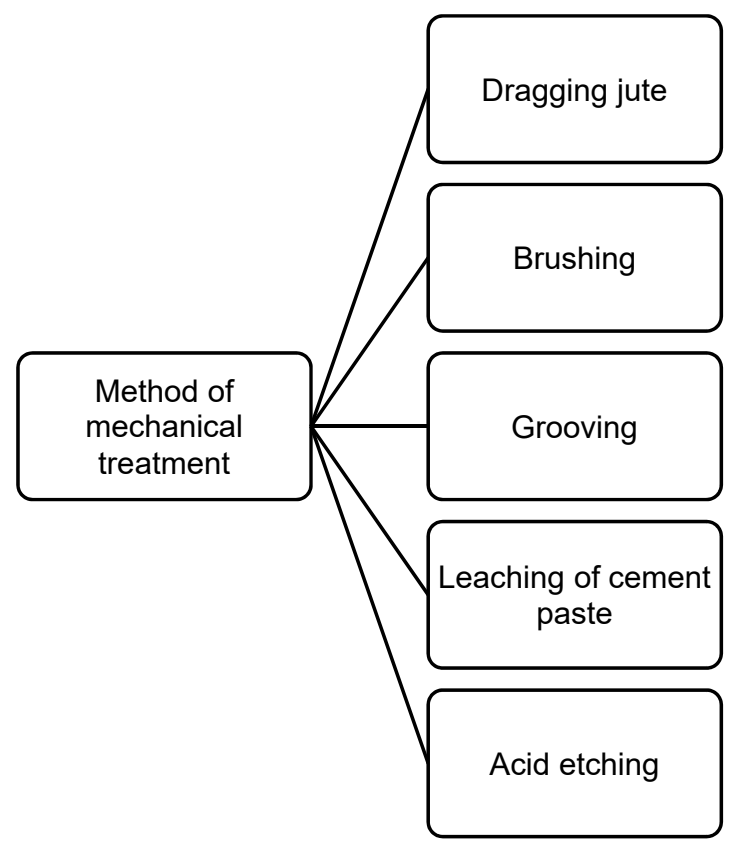

Figure 13. Division of concrete texturing methods.

From the methods presented in Figure 13, dragging the jute texturing method is based on mechanical or manual pulling of the jute fabric over the concrete surface. It is a cheap method, but the texture that is created according to this method is small (around 0.2 to $0.6 \mathrm{~mm}$ ). The brushing method consists of brushing the fresh concrete mix using steel brushes. It can be performed at a texture depth in the range of 2 to $3 \mathrm{~mm}$. The advantage of this method is the fast texturing of the concrete surface. Nevertheless, attention should be paid to the depth of brushing, because too deep texturing can reveal the reinforcement and cause its corrosion. The method that assumes leaching of the cement paste from the cement overlay surface consists of brushing or jetting water that rinses the unbound layer of this 
mortar. Increasing the friction coefficient of the surface is the advantage of this method, despite the fact that it is expensive. Moreover, after application of this method, the surface can have a decorative function. The grooving method is based on grooving the concrete surface by using metal forks in order to obtain a series of grooves on the surface (the depth of each groove is around $6 \mathrm{~mm}$ ). The acid etching method is based on applying a hydrochloric acid solution on the concrete surface by brushing. It is an effective method of removing the cement laitance, but it is rather expensive. Texturing has recently been applied to increase the pull-off adhesion $f_{b}$ of epoxy resin coatings to the concrete substrate [51] and cement mortar overlay to the concrete substrate [52].

\subsection{Removal of Cement Laitance from the Concrete Substrate Surface}

It is known that removing the cement laitance from the concrete substrate surface improves the level of the pull-of adhesion $f_{b}$ between the overlay and the substrate [55-57]. Figure 14 shows the relation between the pull-off adhesion $f_{b}$ and the methods of substrate treatment (removing and not-removing the cement laitance). It can be seen from the figure that methods of removing the cement laitance, for example, grinding (P3) or shot-blasting (P4), can increase the level of the pull-off adhesion $f_{b}$ between the overlay and the substrate (compared to methods that do not remove it).

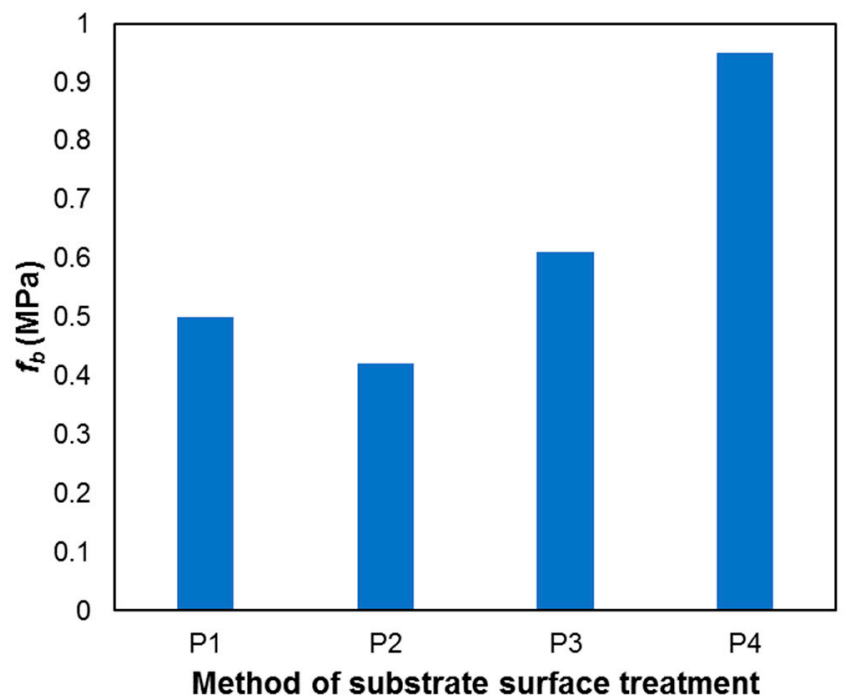

Figure 14. Relation of the pull-off adhesion $f_{b}$ between the overlay and the substrate with regards to the method of treatment of the surface (based on the results presented in Reference [44]). Key: P1—patch grabbed (raw) surface, P2-formed after contact with the surface of formwork (as cast); treatment with removing cement laitance: $\mathrm{P} 3$ - mechanically grinded surface, $\mathrm{P} 4$ - shot-blasted surface.

\subsection{Surface Exposure of the Aggregate}

Sadowski et al. [44] used the 3D laser scanning method to correlate the contribution of exposed aggregate $A_{\mathrm{A}}$ visible on the surface of concrete substrate and being the effect of method of treatment with the value of pull-off adhesion $f_{b}$ between concrete overlay and substrate. Four kinds of concrete surfaces: patched grabbed (raw), formed after contact with the framework (as cast), grinded, and shot-blasted were subjected to the research using an optical microscope. In such a way it was possible to state that the shape of aggregate $A_{\mathrm{A}}$ for the shot-blasted surface in the whole surface was the highest when compared to the surfaces treated in other ways. However, the correlation between the contribution of exposed aggregate $A_{\mathrm{A}}$ that was visible on the concrete surface substrate, and the pull-off adhesion $f_{b}$ between the overlay and this substrate was impossible to obtain. On the other hand, it was shown that an increase of the contribution of exposed aggregate $A_{\mathrm{A}}$ together with increasing the developed interface area ratio $S_{d r}$, causes an increase of the value of pull-off adhesion $f_{b}$. On this basis, the following relation was created: 


$$
f_{b}\left(S_{d r} ; A_{\mathrm{A}}\right)=0.32+0.043 S_{d r}+0.0138 A_{\mathrm{A}}
$$

This equation reveals that the methods of treatment that increase only the developed interface area ratio $S_{d r}$ (patch-grabbed surface and surface formed after contact with framework) do not cause an increase of the pull-off adhesion $f_{b}$. Moreover, an increase of just the contribution of exposed aggregate $A_{\mathrm{A}}$ does not cause an increase of the pull-off adhesion $f_{b}$ (ground surface). Only an increase of the contribution of exposed aggregate $A_{\mathrm{A}}$, together with the developed interface area ratio $S_{d r}$, significantly increases the pull-off adhesion $f_{b}$. This can be seen in the case of the shot-blasted surface.

\subsection{Strengthening of the Surface of the Concrete Substrate with Bonding Agents}

The research has also shown that using a bonding agent before laying the overlay on the concrete substrate surface improves the level of the pull-off adhesion $f_{b}$ of the overlay with the concrete substrate [58-61]. Figure 15 shows the relation between shear bond strength and the method of substrate surface treatment. Moreover, for each method of surface treatment, three methods of applying the added concrete layer are shown: fresh concrete placed against hardened concrete without bonding agent applied in the interface, fresh concrete placed against hardened concrete with bonding agent applied in the interface, hardened concrete placed against hardened concrete with bonding agent applied in the interface.

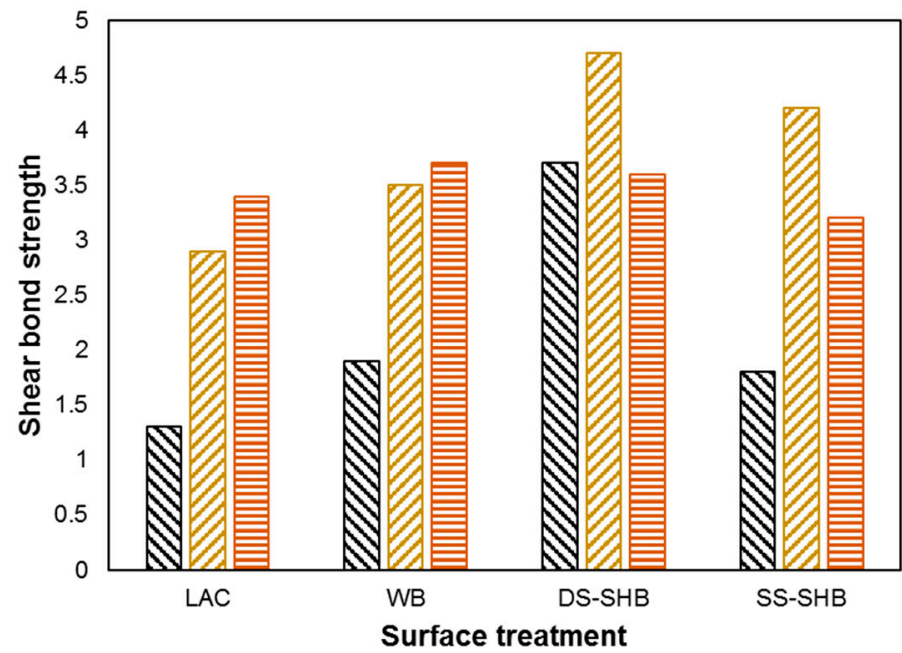

$\triangle$ Fresh concrete placed against hardened concrete without bonding agent

चresh concrete placed against hardened concrete with a bonding agent

$\boxminus$ Hardened concrete placed against hardened concrete with a bonding agent

Figure 15. The relation of shear bond strength with regards to the used bonding agent and the method of surface treatment: LAC — the left as cast surface, WB — the wire-brushed surface, DS-SHB — the dry shot-blasted substrate, SS-SHB - the saturated shot-blasted substrate (based on the results presented in Reference [58]).

As can be seen from the figure, the use of a bonding agent increased the shear bond between layers by almost double for the LAC, WB, and SS-SHB surfaces. The increase of shear bond strength in percentage terms for the DS-SHB surface with a bonding agent was twice as small when compared to the other surfaces (about 25\%). When placing hardened concrete against hardened concrete, a bonding agent, in the case of the LAC and WB surfaces, caused a slight increase of shear bond strength when compared to placing fresh concrete against hardened concrete. In turn, this relation was opposite for the DS-SHB and SS-SHB surfaces. Bonding agents are also popular for increasing the adhesion between gypsum plasters and different substrates [62].

\subsection{Modifications of the Material of the Overlay}

Research has shown that using additions in the form of silica fume, metakaolin, short carbon fibers, polypropylene fiber, styrene/acrylic powder, magnesium phosphate, and fly ash for the cement 
mortar of the overlay is favorable in terms of the level of pull-off adhesion $f_{b}$ between the overlay and the concrete substrate [63-73]). In turn, using quartz and glass powder as an addition to the cement mortar of the overlay does not have a positive influence on the level of its pull-off adhesion $f_{b}[74,75]$. Figure 16 presents the results of bonding strength tests with regards to the polypropylene fiber content in concrete. It can be seen that the addition of PP fiber in amounts of 0.45 and $0.9 \mathrm{~kg} / \mathrm{m}^{3}$ significantly improved bond strength (about double) when compared to the reference concrete $\mathrm{C} 1$. However, the value of bonding strength started to decrease with an increase in PP fiber content (over $0.9 \mathrm{~kg} / \mathrm{m}^{3}$ ).

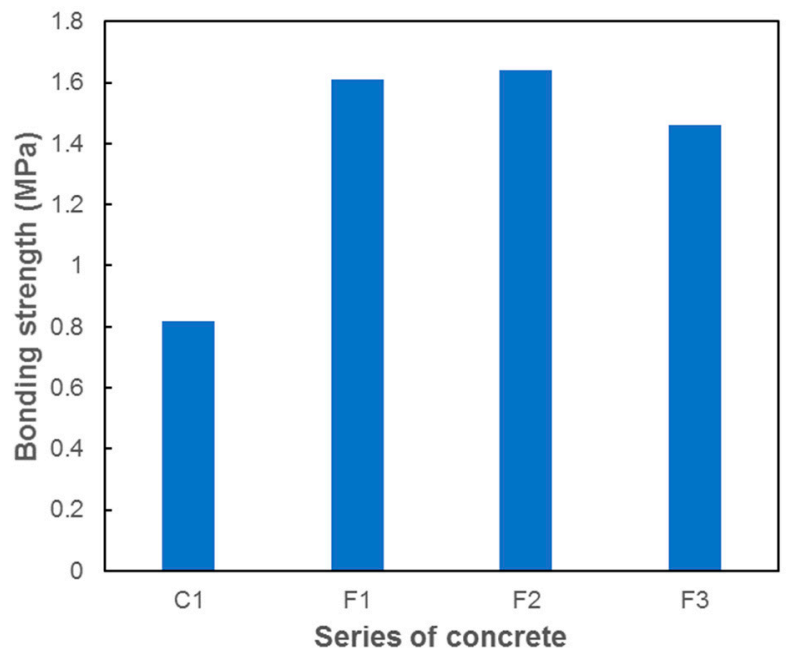

Figure 16. Results of bonding strength tests with regards to the polypropylene fiber content in concrete. C1-concrete without addition, F1-concrete with PP fiber addition in an amount of $0.45 \mathrm{~kg} / \mathrm{m}^{3}$, F2 - concrete with PP fiber addition in an amount of $0.9 \mathrm{~kg} / \mathrm{m}^{3}, \mathrm{~F} 3$ - concrete with PP fiber addition in an amount of $1.35 \mathrm{~kg} / \mathrm{m}^{3}$ (based on the results presented in Reference [73]).

Figure 17 shows the influence of different amounts of quartz powder for modifying overlay concrete on the pull-off adhesion $f_{b}$ between the overlay and the concrete substrate.

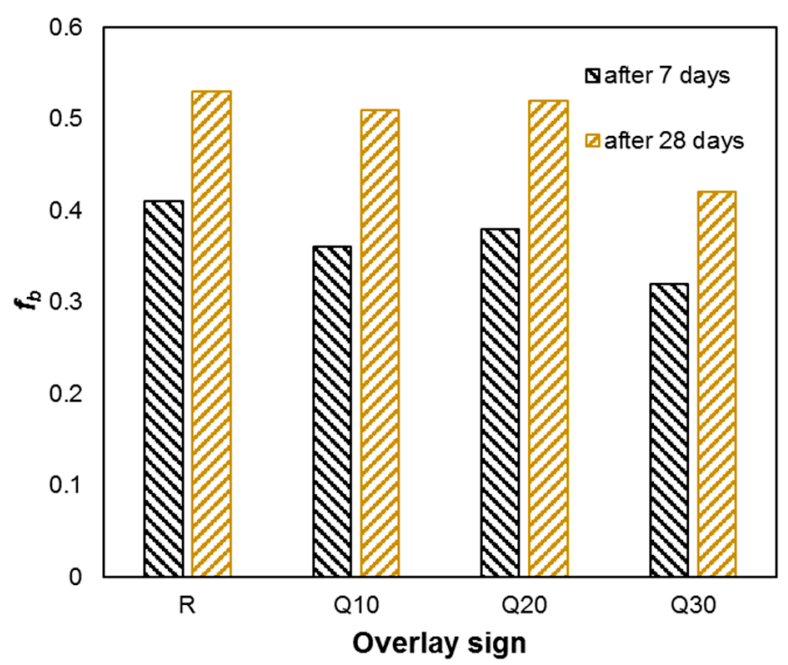

Figure 17. The influence of different amounts of quartz powder for modifying overlay concrete on the pull-off adhesion $f_{b}$ between the overlay and the concrete substrate (based on the results presented in Reference [74]).

As can be seen in Figure 17, the addition of $10 \%$ and $20 \%$ of quartz powder in relation to the cement mass does not cause an increase or decrease of the value of pull-off adhesion $f_{b}$ between the 
overlay and the concrete substrate after 7 and 28 days of testing. In turn, the addition of $30 \%$ of the powder decreased the examined adhesion by around $15 \%$ after 7 days and by around $20 \%$ after 28 days. Figure 18 shows the influence of different amounts of quartz-feldspar powder for modifying overlay concrete on the pull-off adhesion $f_{b}$ between the overlay and concrete substrate.

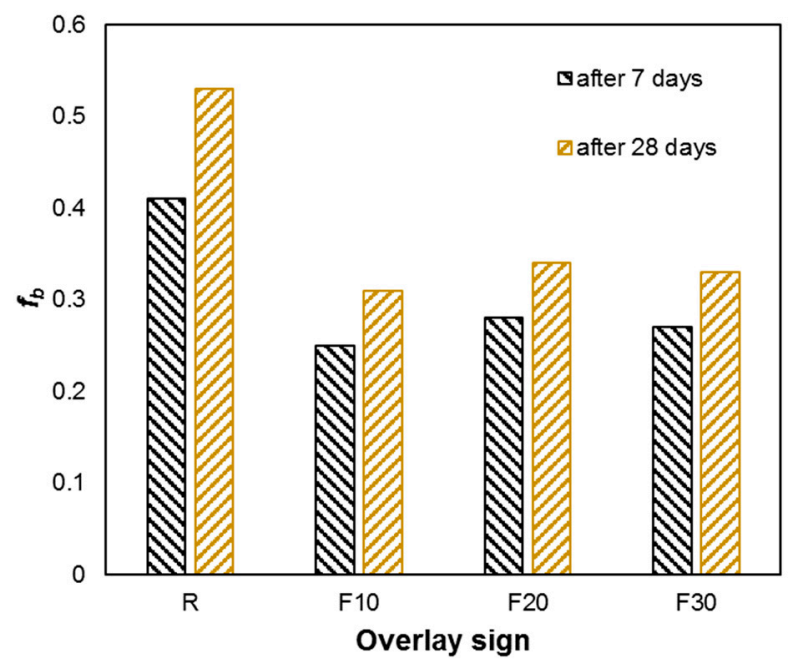

Figure 18. Influence of different amounts of quartz-feldspar powder for modifying overlay concrete on the pull-off adhesion $f_{b}$ between the overlay and concrete substrate (based on the results presented in Reference [74]).

It can be seen in Figure 18 that the addition of quartz-feldspar powder to the overlay in each amount caused around a double decrease in the value of pull-off adhesion $f_{b}$ between the concrete substrate and the overlay.

In Reference [70], the influence of early water exposure on the modified cementitious coating was described. The pull-off tests were performed to assess the influence. Figure 19 shows the relation between average tensile strength and time. The red curves are connected with the polymer coating, and the blue curves with the crystalline coating.

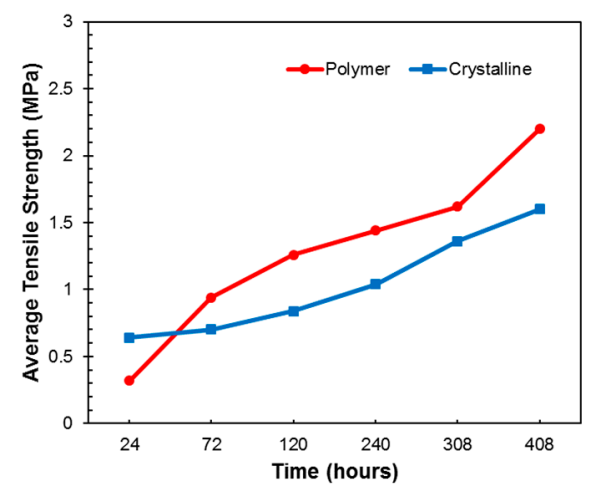

(a)

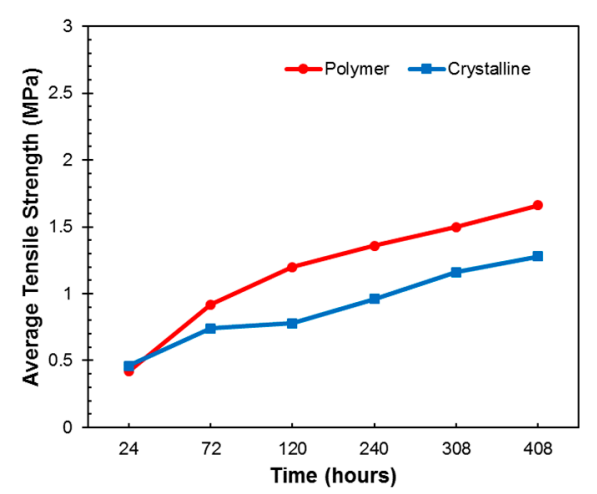

(b)

Figure 19. The relation between the average tensile strength (pull-off strength) and time for the polymer and crystalline coating: (a) rough substrate, (b) smooth substrate (based on the results presented in Reference [70]).

It can be seen from Figure 19a,b that the level of pull-off strength for the polymer coating was greater than for the crystalline coating. However, both coatings resulted in a pull-off strength greater than $1 \mathrm{MPa}$ (after $120 \mathrm{~h}$ for the polymer coating and after $240 \mathrm{~h}$ for the crystalline coating). 


\section{Overview of Recent Activities Used to Improve the Functional Properties of the Overlay}

Depending on the functional requirements of an object, as well as its durability, overlays should have proper strength and functional parameters [76,77]. The chosen parameters are shown in Table 1.

Table 1. The list of chosen strengths and functional parameters for floors.

\begin{tabular}{cc}
\hline Parameter & Value \\
\hline Compressive strength & Minimum 20 MPa \\
Flexural strength & Minimum $5 \mathrm{MPa}$ \\
Subsurface tensile strength & Minimum $1.5 \mathrm{MPa}$ \\
Abrasion resistance & Maximum $22 \mathrm{~cm}^{3}$ \\
Hardness & Determined individually \\
\hline
\end{tabular}

In many cases, the failure to comply with technological and technical requirements has a negative effect on the condition of cement mortar floors [78]. In order to obtain parameters to the required level, the following additional activities, which are shown in Figure 20, are used:

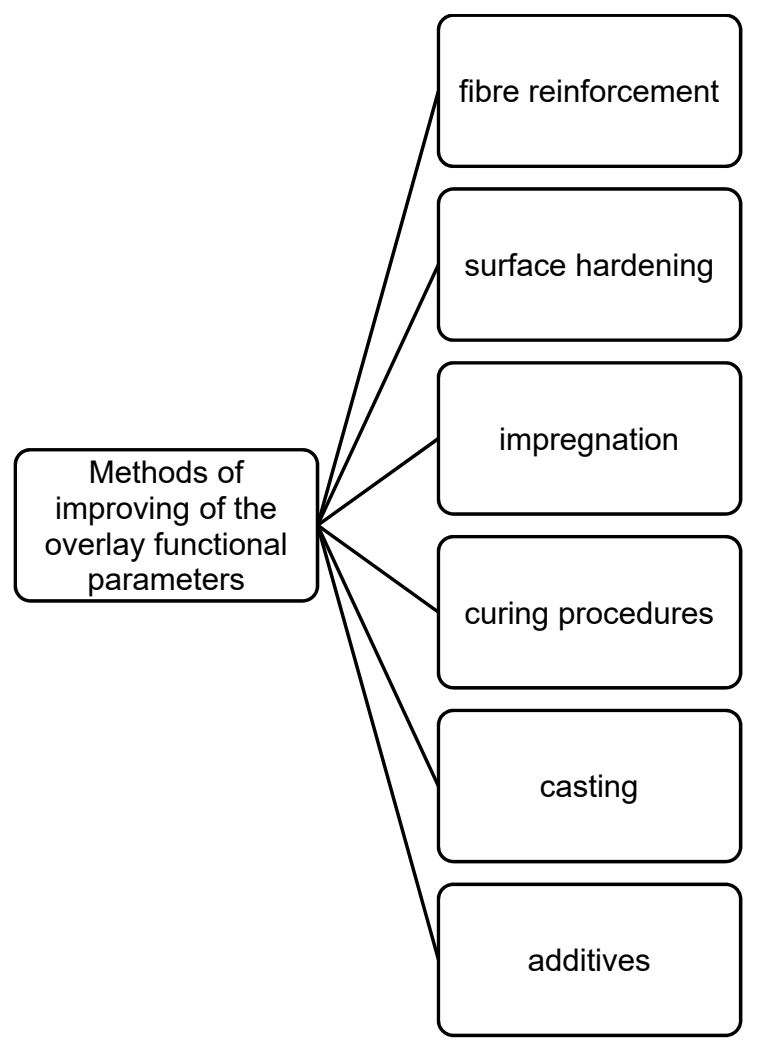

Figure 20. Methods of improving the overlay functional parameters.

Different types of fiber, such as polypropylene, polyethylene, nylon, aramid, and polyester are also commonly used as an additive to concrete in order to improve its mechanical and functional properties [79-84]. However, the most common overlay additives are polypropylene fibers [85]. In Reference [73], it was stated that the addition of polypropylene to concrete improves, among others, its compressive and flexural strength, impact resistance, and abrasion resistance. In turn, Song and Hwang [86] indicated that adding steel fiber to concrete increases its compressive strength by up to $15.3 \%$ and its splitting tensile strength by up to $98.3 \%$. In general, an increase in compressive strength can improve abrasion resistance and subsurface tensile strength [87-90]. Despite this relation, the value of compressive strength can differ in the upper, middle, and bottom zone of the overlay [91,92], which 
was proved by the carried out ultrasonic testing of the overlays [93,94]. The tensile strength, drying shrinkage, elastic modulus, and tensile relaxation of the overlay are affected to a great extent by curing conditions [57,95-97]. It was also reported that the properties of concrete may be affected by the manner of casting [98-100]. The next method of improving overlay functional properties is surface hardening. Many hardeners, such as mineral or metallic aggregate hardeners (iron, quartz, silica, corindon, etc.), polypropylene fibers, and metallic fibers [101-105] have been found to especially increase the abrasion resistance of the surface of concrete and mortar. The method of finishing and modifying the overlay material with micro/nano materials not only affects the abrasion resistance [106-114], but also different special properties such as aging resistance in high temperatures, self-cleaning, air purification, de-icing salt resistance or freeze/thaw resistance [115-119]. Impregnation of the surface of the overlay by different coatings (e.g., epoxy, acrylic, polyurethane, cementitious, polymer/clay nanocomposites) can increase its durability, as well as improve many functional parameters such as adhesive resistant, chemical resistance, chloride permeability, hardness, impermeability, abrasion resistance, heat resistance, shrinkage, etc. [120-129].

\section{Perspectives and Research Gaps}

It is shown in literature that modification of the mortar cement composition of the overlay with the addition of nanoparticles can increase the pull-off adhesion $f_{b}$ between the overlay and the concrete substrate. However, there is a lack of wider research concerning this problem $[130,131]$. Figure 21 presents the values of pull-off adhesion $f_{b}$ with regards to the concrete mixture type. The pull-off adhesion $f_{b}$ was determined before and after freezing/thawing and wetting/drying cycles. Letters $\mathrm{A}$ and B refer to concrete with the addition of 15 (A) and $30 \%$ of fly ash (B). For the other symbols, the number refers to the replacement of fly ash by the mass of the binder, $\mathrm{N}$ refers to normal-setting concrete mixture, and $\mathrm{R}$ refers to rapid-setting concrete mixture. Each mixture marked with numbers had a $6 \%$ dosage of nano silica (by the mass of the binder).

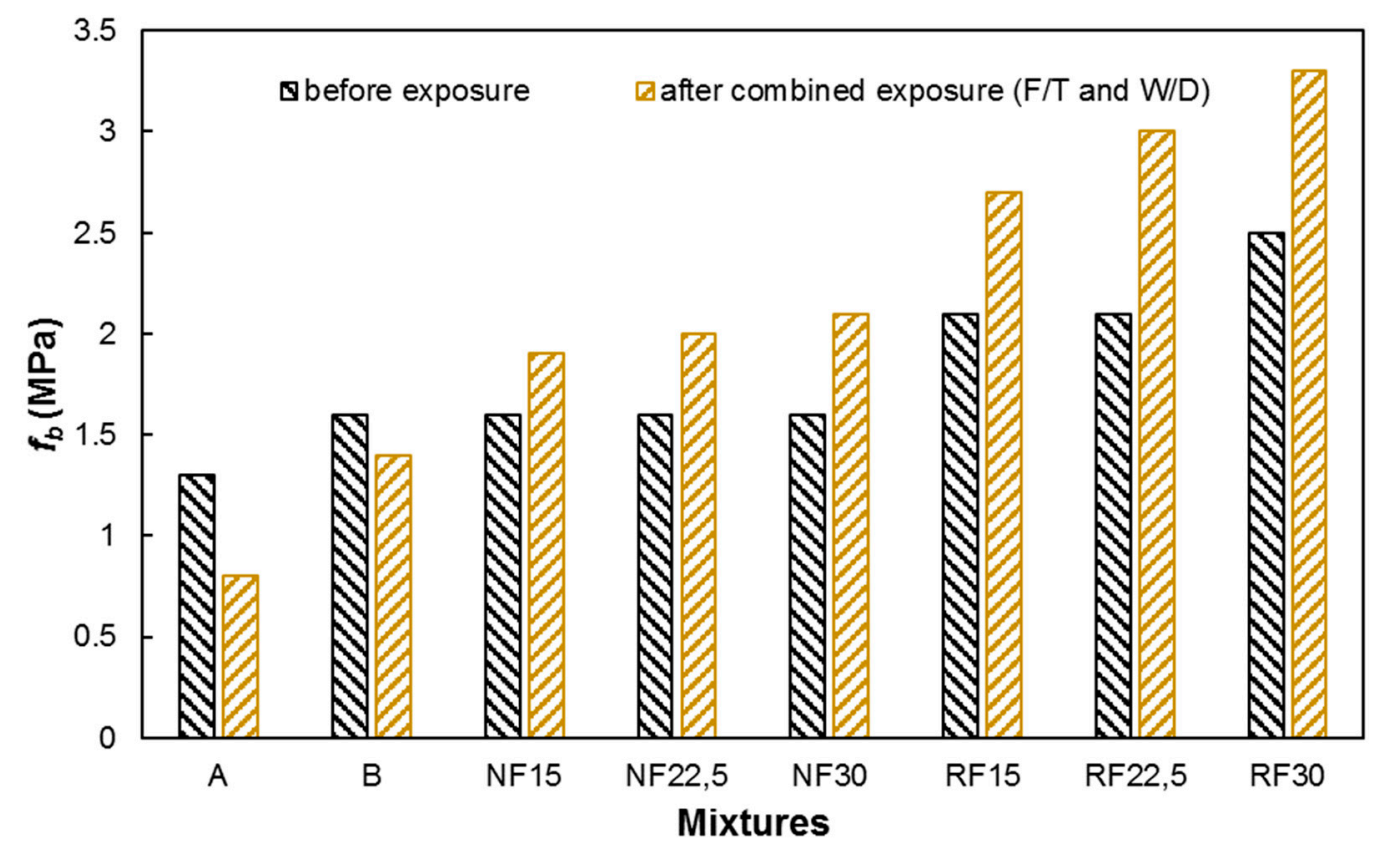

Figure 21. Pull-off adhesion $f_{b}$ of the repair assembly from pull-off test (based on the results presented in Reference [131]).

It can be seen in Figure 21 that the values of pull-off adhesion $f_{b}$ for the A (1.3 MPa) and B (1.6 MPa) series were the lowest, and after F/T and W/D cycle exposure the values fell approximately by 30 to 
$50 \%$. For the $\mathrm{N}$ and R series, the pull-off adhesion $f_{b}$ values were in the range of 1.9 to $3.3 \mathrm{MPa}$, and after the F/T and W/D cycles the values increased approximately by 23 to $43 \%$.

In Table 2, the so far studied features of concrete and mortars modified with the addition of nanoparticles are shown. The type of examined nanoparticles is shown in the upper part of the table, and the examined features are shown on the left. However, attention should be paid to the fact that there is a lack of research concerning the pull-off adhesion $f_{b}$ between the overlay and concrete substrate and subsurface tensile strength.

Table 2. Selectively examined features of cement mortar and concrete with the addition of nanoparticles. (+ examined, - no data)

\begin{tabular}{cccccccc}
\hline Examined Feature & \multicolumn{7}{c}{ The Kind of Nanoparticle } \\
\cline { 2 - 7 } & $\mathrm{SiO}_{2}$ & $\mathrm{Al}_{2} \mathrm{O}_{3}$ & $\mathrm{CuO}$ & $\mathrm{TiO}_{2}$ & $\mathrm{ZnO}_{2}$ & $\mathrm{Fe}_{2} \mathrm{O}_{3}$ & $\mathrm{Cr}_{2} \mathrm{O}_{3}$ \\
\hline Porosity & + & + & + & + & + & - & + \\
Absorptiveness & - & - & - & - & - & + & + \\
Water resistance & - & - & - & + & - & - & - \\
Freeze-thaw durability & + & + & - & + & - & - & - \\
Compressive strength & + & + & + & + & - & + & + \\
Tensile strength & + & - & - & - & - & + & + \\
Flexural strength & + & + & - & - & + & + & + \\
Abrasion resistance & + & + & + & + & - & - & - \\
Hardness & + & - & - & - & - & - & + \\
Subsurface tensile strength & - & - & - & - & - & - & - \\
Pull-off adhesion between overlay & - & - & - & - & - & - & - \\
and concrete substrate & - & - & - & & &
\end{tabular}

To sum up, there is a lack of research results concerning the influence of nanoparticles included in the cement mortar of the overlay in concrete floors on the level of its pull-off adhesion $f_{b}$ between the overlay and concrete substrate, as well as on its functional parameters.

\section{Conclusions}

The aim of this article was to briefly introduce readers to the problem of the adhesion between overlays and substrates in concrete floors and to illustrate the current state of knowledge on the subject. The recently used non-destructive and semi-destructive testing methods and the parameters useful for characterizing the adhesion between overlays and substrates in concrete floors, as well as methods useful for characterizing the functional properties of the overlays were presented. The literature survey, with special emphasis on the critical review of the current research results and research gaps, was presented. On this basis, future research directions were highlighted. Specific conclusions and research gaps are listed as follows:

1. Additional research should be carried out in order to assess the influence of modifying a mortar overlay using other nanoparticles on the pull-off adhesion $f_{b}$ between the overlay and the concrete substrate. The functional and mechanical properties (such as abrasion resistance, flexural strength, compressive strength, subsurface tensile strength) of the overlay should be taken into consideration together with the values of pull-off adhesion $f_{b}$. Julio et al. [130] and Ghazy and Bassuoni [131] used $\mathrm{SiO}_{2}$ and $\mathrm{Al}_{2} \mathrm{O}_{3}$ nanoparticles to increase the shear bond strength between concrete layers. However, there is still a lack of wider research in this field.

2. Additional research should be carried out in order to better understand the mechanism of adhesion between an overlay modified with different types of nanoparticles and the concrete substrate on a micro- and nanoscale of observation. The samples taken from the interphase zone between the overlay and the substrate, together with the sample from the subsurface zone of the overlay, should be examined in order to understand and confirm the influence of the addition of 
nanoparticles on the adhesion and functional and mechanical parameters. The scanning electron microscopy (SEM) method can be especially suitable for this purpose.

3. Nanoparticles could be successfully used to reduce the porosity of the cementitious material of the overlay in the near surface zone of the mortar overlay, together with proper treatment of the surface of the concrete substrate, to increase the pull-off adhesion $f_{b}$ between these layers. The studies carried out by Sadowski and Stefaniuk $[50,53]$ reported that while decreasing the fraction and number of pores in the near surface zone of the overlay mortar, and increasing these values in the near surface zone of the concrete substrate, the pull-off adhesion $f_{b}$ between these layers increases.

Funding: This research received no external funding.

Conflicts of Interest: The authors declare no conflict of interest.

\section{References}

1. Hoła, J.; Bień, J.; Sadowski, Ł.; Schabowicz, K. Non-destructive and semi-destructive diagnostics of concrete structures in assessment of their durability. Bull. Pol. Acad. Sci. Tech. Sci. 2015, 63, 87-96. [CrossRef]

2. Garber, G. Design and Construction of Concrete Floors; CRC Press: Boca Raton, FL, USA, 2006.

3. Tejchman, J.; Małaśkiewicz, A. Industrial Floors; Wydawnictwo Politechniki Gdańskiej: Gdańsk, Poland, 2006; Volume 181, ISBN 83-7348-166-4. (In Polish)

4. Jasiczak, J.; Szymański, P. Technologia i Wykonanie Posadzek Betonowych w Aspekcie Skurczu i Pielegnacji Betonu. Mater. Bud. 2006, 9, 16-19.

5. Sadowski, Ł. Adhesion in Layered Cement Composites; Springer International Publishing: Cham, Switzerland, 2019; ISBN 978-3-030-03782-6. [CrossRef]

6. Zybura, A.; Jaśniok, M.; Jaśniok, T. Diagnostics of Concrete Structures; Wydawnictwo Naukowe PWN: Warszawa, Poland, 2017. (In Polish)

7. Bissonnette, B.; Courard, L.; Garbacz, A. Concrete Surface Engineering; CRC Press: Boca Raton, FL, USA, 2015.

8. Czarnecki, L.; Van Gemert, D. Scientific basis and rules of thumb in civil engineering: conflict or harmony? Bull. Pol. Acad. Sci. Tech. Sci. 2016, 64, 665-673. [CrossRef]

9. Hola, J.; Sadowski, L.; Schabowicz, K. Nondestructive identification of delaminations in concrete floor toppings with acoustic methods. Autom. Constr. 2011, 20, 799-807. [CrossRef]

10. Sadowski, Ł. Non-destructive Evaluation of the Adhesion between Concrete Layers in Concrete Floors with Using the Artificial Neural Networks. Ph.D. Thesis, Wroclaw University of Science and Technology, Wrocław, Poland, 2012.

11. Sadowski, Ł. Multi-Scale Evaluation of the Interphase Zone between the Overlay and Concrete Substrate: Methods and Descriptors. Appl. Sci. 2017, 7, 893. [CrossRef]

12. Momayez, A.; Ehsani, M.; Ramezanianpour, A.; Rajaie, H. Comparison of methods for evaluating bond strength between concrete substrate and repair materials. Cem. Concr. Res. 2005, 35, 748-757. [CrossRef]

13. British Standards Institution. EN 1542:2000. Products and Systems for the Protection and Repair of Concrete Structures. Test Methods. Measurement of Bond Strength by Pull-Off; British Standards Institution: London, UK, 1999.

14. Cleland, D.; Long, A. The pull-off test for concrete patch repairs. In Proceedings of the Institution of Civil Engineers-Structures Buildings, London, UK, November 1997; Volume 122, pp. 451-460.

15. Czarnecki, L.; Chmielewska, B. Factors Affecting Adhesion in Building Joints; Cement. Lime. Concrete 2; Cement Lime Concrete Fundation: Cracow, Poland, 2005; pp. 74-85.

16. British Standards Institution. EN 1504-3. Products and Systems for the Protection and Repair of Concrete Structures-Definitions, Requirements, Quality Control and Evaluation of Conformity; Part 3: Structural and Non-Structural Repair; British Standards Institution: London, UK, 2004.

17. British Standards Institution. EN 13892-3. Methods of Test for Screed Materials. Determination of Wear Resistance-Böhme; British Standards Institution: London, UK, 2014.

18. British Standards Institution. EN 1504-10. Products and Systems for the Protection and Repair of Concrete Structures-Definitions, Requirements, Quality Control and Evaluation of Conformity; Part 10: Site Application of Products and Systems and Quality Control of the Works; British Standards Institution: London, UK, 2017. 
19. Malhotra, M.V.; Carino, N.J. Handbook on Nondestructive Testing of Concrete; CRC Press: Boca Raton, FL, USA, 2003.

20. Brunarski, L.; Runkiewicz, L. ITB Instruction No 210. Non-Destructive Methods for Testing Concrete Strength, Sclerometric Methods, Experimental Instruction; Building Technique Institute: Warsaw, Poland. (In Polish)

21. Lataste, J.; Krause, M.; Moczko, A.; Breysse, D.; Maierhofer, C. Nondestructive Evaluation of Delaminations and Interfaces in Concrete Structures. RILEM Publications SARL, 2008. Available online: https://www.rilem. net/publication/publication/63 (accessed on 15 June 2019).

22. British Standards Institution. EN 12504-2. Testing Concrete in Structures. Non-destructive Testing-Determination of Rebound Number; British Standards Institution: London, UK, 2012.

23. Drobiec, Ł. Non-destructive Tests Used in Civil Engineering; Badania Nieniszczace i Diagnostyka: Kołobrzeg, Poland, 2018; Volume 3, pp. 76-80. (In Polish)

24. Chady, T.; Sikora, R. Non-Destructive Testing: History, Current State and Perspectives; Przeglad Spawalnictwa: Warsaw, Poland, 2013; pp. 13-15. (In Polish)

25. Runkiewicz, L. Testing of Concrete Structures; Biuro Gamma: Warszawa, Poland, 2002. (In Polish)

26. Bień, J. Uszkodzenia i Diagnostyka Obiektów Mostowych; Wydawnictwa Komunikacji i Łączności: Warszawa, Poland, 2010.

27. Hoła, J.; Schabowicz, K. State-of-the-art non-destructive methods for diagnostic testing of building structures-anticipated development trends. Arch. Civ. Mech. Eng. 2010, 10, 5-18. [CrossRef]

28. Schabowicz, K. Neural networks in the NDT identification of the strength of concrete. Arch. Civ. Eng. 2005, 51, 371-382.

29. Ongpeng, J.M.C.; Oreta, A.W.C.; Hirose, S. Investigation on the Sensitivity of Ultrasonic Test Applied to Reinforced Concrete Beams Using Neural Network. Appl. Sci. 2018, 8, 405. [CrossRef]

30. Ongpeng, J.; Soberano, M.; Oreta, A.; Hirose, S. Artificial neural network model using ultrasonic test results to predict compressive stress in concrete. Comput. Concr. 2017, 19, 59-68. [CrossRef]

31. Hoła, J.; Schabowicz, K. New technique of nondestructive assessment of concrete strength using artificial intelligence. NDT E Int. 2005, 38, 251-259. [CrossRef]

32. Hola, J.; Schabowicz, K. Methodology of neural identification of strength of concrete. ACI Mater. J. 2005, $102,459$.

33. Sadowski, Ł.; Czarnecki, S.; Hoła, J. Evaluation of the height 3D roughness parameters of concrete substrate and the adhesion to epoxy resin. Int. J. Adhes. Adhes. 2016, 67, 3-13. [CrossRef]

34. Abu-Tair, A.; Lavery, D.; Nadjai, A.; Rigden, S.; Ahmed, T. A new method for evaluating the surface roughness of concrete cut for repair or strengthening. Constr. Build. Mater. 2000, 14, 171-176. [CrossRef]

35. Branco, F.A.B.; Silva, V.D.; Júlio, E.N.B.S. Concrete-to-concrete bond strength: influence of an epoxy-based bonding agent on a roughened substrate surface. Mag. Concr. Res. 2005, 57, 463-468.

36. Garbacz, A.; Górka, M.; Courard, L. Effect of concrete surface treatment on adhesion in repair systems. Mag. Concr. Res. 2005, 57, 49-60. [CrossRef]

37. Courard, L. Adhesion of repair systems to concrete: influence of interfacial topography and transport phenomena. Mag. Concr. Res. 2005, 57, 273-282. [CrossRef]

38. Santos, P.M.D.; Júlio, E.N.B.S. Comparison of Methods for Texture Assessment of Concrete Surfaces. ACI Mater. J. 2010, 107, 433-440.

39. Mathia, T.G.; Pawlus, P.; Wieczorowski, M. Recent trends in surface metrology. Wear 2011, 271, 494-508. [CrossRef]

40. Garbacz, A.; Courard, L.; Bissonnette, B. A surface engineering approach applicable to concrete repair engineering. Bull. Pol. Acad. Sci. Tech. Sci. 2013, 61, 73-84. [CrossRef]

41. Al-Kheetan, M.J.; Rahman, M.M.; Chamberlain, D.A. A novel approach of introducing crystalline protection material and curing agent in fresh concrete for enhancing hydrophobicity. Constr. Build. Mater. 2018, 160, 644-652. [CrossRef]

42. Scarfato, P.; Maio, L.D.; Fariello, M.L.; Russo, P.; Incarnato, L. Preparation and evaluation of polymer/clay nanocomposite surface treatments for concrete durability enhancement. Cem. Concr. Compos. 2012, 34, $297-305$. [CrossRef]

43. Hassan, M.M.; Dylla, H.; Mohammad, L.N.; Rupnow, T. Evaluation of the durability of titanium dioxide photocatalyst coating for concrete pavement. Constr. Build. Mater. 2010, 24, 1456-1461. [CrossRef] 
44. Sadowski, Ł.; Żak, A.; Hoła, J. Multi-sensor evaluation of the concrete within the interlayer bond with regard to pull-off adhesion. Arch. Civ. Mech. Eng. 2018, 18, 573-582. [CrossRef]

45. Santos, P.M.; Júlio, E.N.; Silva, V.D. Correlation between concrete-to-concrete bond strength and the roughness of the substrate surface. Constr. Build. Mater. 2007, 21, 1688-1695. [CrossRef]

46. Garbacz, A.; Courard, L.; Kostana, K. Characterization of concrete surface roughness and its relation to adhesion in repair systems. Mater. Charact. 2006, 56, 281-289. [CrossRef]

47. Courard, L.; Piotrowski, T.; Garbacz, A. Near-to-surface properties affecting bond strength in concrete repair. Cem. Concr. Compos. 2014, 46, 73-80. [CrossRef]

48. Tayeh, B.B.; Bakar, B.H.A.; Johari, M.A.M.; Ratnam, M.M. The relationship between substrate roughness parameters and bond strength of ultra high-performance fiber concrete. J. Adhes. Sci. Technol. 2013, $27,21$. [CrossRef]

49. Franck, A.; De Belie, N. Concrete Floor-Bovine Claw Contact Pressures Related to Floor Roughness and Deformation of the Claw. J. Dairy Sci. 2006, 89, 2952-2964. [CrossRef]

50. Sadowski, Ł.; Stefaniuk, D.; Hoła, J. The effect of the porosity within the interfacial zone between layers on pull-off adhesion. Constr. Build. Mater. 2017, 152, 887-897. [CrossRef]

51. Krzywiński, K.; Sadowski, Ł. The Effect of Texturing of the Surface of Concrete Substrate on the Pull-Off Strength of Epoxy Resin Coating. Coatings 2019, 9, 143. [CrossRef]

52. Sadowski, Ł.; Krzywiński, K.; Michoń, M. The influence of texturing of the surface of concrete substrate on its adhesion to cement mortar overlay. J. Adhes. 2019. [CrossRef]

53. Sadowski, Ł.; Stefaniuk, D. Microstructural Evolution within the Interphase between Hardening Overlay and Existing Concrete Substrates. Appl. Sci. 2017, 7, 123. [CrossRef]

54. Misra, A.; Cleland, D.J.; Basheer, P.A.M. Effect of different substrate and overlay concretes on bond strength and interfacial permeability. Concr. Sci. Eng. 2001, 3, 73-77.

55. Silfwerbrand, J.; Beushausen, H. Bonded concrete overlays-Bond strength issues. In Concrete Repair, Rehabilitaion and Retrofitting; Alexander, M., Beushausen, H.-D., Dehn, F., Moyo, P., Eds.; Taylor Francis Group: London, UK, 2006.

56. Silfwerbrand, J.; Beushausen, H.; Courard, L. Bonded Cement-Based Material Overlays for the Repair, the Lining or the Strengthening of Slabs or Pavements. In RILEM State of the Art Reports; Bissonnette, B., Courard, L., Fowler, D., Granju, J.L., Eds.; Springer: Dordrecht, The Netherlands, 2011; Volume 3.

57. Kosmatka, S.H.; Kerkhoff, B.; Panarese, W.C. Design and Control of Concrete Mixtures; Portland Cement Association: Skokie, IL, USA, 2002; Volume 5420.

58. Santos, D.S.; Santos, P.M.; Dias-Da-Costa, D. Effect of surface preparation and bonding agent on the concrete-to-concrete interface strength. Constr. Build. Mater. 2012, 37, 102-110. [CrossRef]

59. Xiong, G.; Liu, J.; Li, G.; Xie, H. A way for improving interfacial transition zone between concrete substrate and repair materials. Cem. Concr. Res. 2002, 32, 1877-1881. [CrossRef]

60. Xiong, G.; Luo, B.; Wu, X.; Li, G.; Chen, L. Influence of silane coupling agent on quality of interfacial transition zone between concrete substrate and repair materials. Cem. Concr. Compos. 2006, 28, 97-101. [CrossRef]

61. Błaszczyński, T.; Jasiczak, J.; Ksit, B.; Siewczyńska, M. Aspects of bond layer role in concrete repairs. Arch. Civ. Mech. Eng. 2006, 6, 75-87. [CrossRef]

62. Krzywiński, K.; Sadowski, Ł.; Łaszczak, M. The effect of the type of substrate and its surface treatment on the pull-off strength of gypsum plasters. J. Adhes. 2019. [CrossRef]

63. Mohammadi, M.; Moghtadaei, R.M.; Samani, N.A. Influence of silica fume and metakaolin with two different types of interfacial adhesives on the bond strength of repaired concrete. Constr. Build. Mater. 2014, 51, 141-150. [CrossRef]

64. Mirmoghtadaei, R.; Mohammadi, M.; Samani, N.A.; Mousavi, S. The impact of surface preparation on the bond strength of repaired concrete by metakaolin containing concrete. Constr. Build. Mater. 2015, 80, 76-83. [CrossRef]

65. Sadowski, Ł.; Piechówka-Mielnik, M.; Widziszowski, T.; Gardynik, A.; Mackiewicz, S. Hybrid ultrasonic-neural prediction of the compressive strength of environmentally friendly concrete screeds with high volume of waste quartz mineral dust. J. Clean. Prod. 2019, 212, 727-740. [CrossRef]

66. El-Rakib, T.M.; Farahat, A.M.; El-Degwy, W.M.; Shaheen, H.H. Shear transfer parameters at the interface between old and new concrete. In Proceedings of the International Conference on Performance of Construction Materials in the New Millennium, Cairo, Egypt, 18-20 February 2003. 
67. Qin, J.; Qian, J.; You, C.; Fan, Y.; Li, Z.; Wang, H. Bond behavior and interfacial micro-characteristics of magnesium phosphate cement onto old concrete substrate. Constr. Build. Mater. 2018, 167, 166-176. [CrossRef]

68. Li, B.; Lam, E.S.S. Influence of interfacial characteristics on the shear bond behaviour between concrete and ferrocement. Constr. Build. Mater. 2018, 176, 462-469. [CrossRef]

69. Gengying, L. A new way to increase the long-term bond strength of new-to-old concrete by the use of fly ash. Cem. Concr. Res. 2003, 33, 799-806.

70. Al-Kheetan, M.J.; Rahman, M.M.; Chamberlain, D.A. Influence of early water exposure on modified cementitious coating. Constr. Build. Mater. 2017, 141, 64-71. [CrossRef]

71. Tayeh, B.A.; Bakar, B.A.; Johari, M.M.; Voo, Y.L. Evaluation of bond strength between normal concrete substrate and ultra high performance fiber concrete as a repair material. Procedia Eng. 2013, 54, 554-563. [CrossRef]

72. Schulze, J. Influence of water-cement ratio and cement content on the properties of polymer-modified mortars. Cem. Concr. Res. 1999, 29, 909-915. [CrossRef]

73. Sun, Z.; Xu, Q. Microscopic, physical and mechanical analysis of polypropylene fiber reinforced concrete. Mater. Sci. Eng. A 2009, 527, 198-204. [CrossRef]

74. Sadowski, Ł.; Hoła, J. Wpływ wybranych kwarcowych dodatków mineralnych modyfikujących beton warstwy wierzchniej na jego zespolenie z podkładem betonowym. Budownictwo o Zoptymalizowanym Potencjale Energetycznym 2017, 1, 21-26. [CrossRef]

75. Sadowski, Ł. Towards the utilization of waste glass powder in sustainable cement based overlays. In MATEC Web of Conferences; EDP Sciences: Julius, France, 2018; Volume 163, p. 03001.

76. Śliwiński, J. Podstawowe właściwości betonu i jego trwałość. Cem. Wapno Beton 2009, 5, 245-254.

77. Jamroży, Z. Beton i jego technologie; Państwowe Wydawnictwo Naukowe: Warszawa/Kraków, Poland, 2005.

78. Hoła, J.; Sadowski, Ł.; Hoła, A. The effect of failure to comply with technological and technical requirements on the condition of newly built cement mortar floors. Proc. Inst. Mech. Eng. Part L J. Mater. Des. Appl. 2019, 233, 268-275. [CrossRef]

79. Banthia, N.; Sheng, J. Fracture toughness of micro-fiber reinforced cement composites. Cem. Concr. Compos. 1996, 18, 251-269. [CrossRef]

80. Chajec, A.; Krzywiński, K.; Sadowski, Ł.; Ostrowski, K. The influence of polypropylene fibres on the properties of fresh and hardened concrete. Czas. Tech. 2019, 5, 71-82. [CrossRef]

81. Krzywiński, K.; Chajec, A.; Sadowski, Ł. The effect of the concentration of steel fibres on the properties of industrial floors. Czas. Tech. 2019, 4, 115-132. [CrossRef]

82. Mu, B.; Li, Z.; Peng, J. Short fiber-reinforced cementitious extruded plates with high percentage of slag and different fibers. Cem. Concr. Res. 2000, 30, 1277-1282. [CrossRef]

83. Bayasi, M.Z.; Zeng, J. Composite slab construction utilizing carbon fiber reinforced mortar. Struct. J. 1997, 94, 442-446.

84. Banthia, N.; Gupta, R. Influence of polypropylene fiber geometry on plastic shrinkage cracking in concrete. Cem. Concr. Res. 2006, 36, 1263-1267. [CrossRef]

85. Kim, S.B.; Yi, N.H.; Kim, H.Y.; Kim, J.-H.J.; Song, Y.-C. Material and structural performance evaluation of recycled PET fiber reinforced concrete. Cem. Concr. Compos. 2010, 32, 232-240. [CrossRef]

86. Song, P.; Hwang, S. Mechanical properties of high-strength steel fiber-reinforced concrete. Constr. Build. Mater. 2004, 18, 669-673. [CrossRef]

87. Atiş, C.D. High Volume Fly Ash Abrasion Resistant Concrete. J. Mater. Civ. Eng. 2002, 14, 274-277. [CrossRef]

88. Kılıç, A.; Atiş, C.; Teymen, A.; Karahan, O.; Özcan, F.; Bilim, C.; Ozdemir, M.; Kilic, A. The influence of aggregate type on the strength and abrasion resistance of high strength concrete. Cem. Concr. Compos. 2008, 30, 290-296. [CrossRef]

89. Siewczyńska, M.; Jasiczak, J. Wpływ wybranych parametrów betonu na przyczepność powłok naprawczych. Mater. Bud. 2009, 2, 10-11.

90. Siewczyńska, M. Wpływ Wybranych Parametrów Betonu na Przyczepność Powłok Ochronnych; Rozprawa Doktorska: Poznań, Poland, 2008.

91. Canbaz, M.; Topçu, I.B.; Ateşin, Ö. Effect of admixture ratio and aggregate type on self-leveling screed properties. Constr. Build. Mater. 2016, 116, 321-325. [CrossRef] 
92. Khatib, J.; Mangat, P.; Khatib, J. Porosity of cement paste cured at $45^{\circ} \mathrm{C}$ as a function of location relative to casting position. Cem. Concr. Compos. 2003, 25, 97-108. [CrossRef]

93. Stawiski, B. The heterogeneity of mechanical properties of concrete in formed constructions horizontally. Arch. Civ. Mech. Eng. 2012, 12, 90-94. [CrossRef]

94. Stawiski, B.; Radzik, Ł. Need to Identify Parameters of Concrete in the Weakest Zone of the Industrial Floor. IOP Conf. Ser. Mater. Sci. Eng. 2017, 245, 22063. [CrossRef]

95. Beushausen, H.; Bester, N. The influence of curing on restrained shrinkage cracking of bonded concrete overlays. Cem. Concr. Res. 2016, 87, 87-96. [CrossRef]

96. Neville Adam, M. Properties of Concrete; Longman: London, UK, 1995; Volume 4.

97. Parghi, A.; Alam, M.S.; Parghi, P.A. Effects of curing regimes on the mechanical properties and durability of polymer-modified mortars-An experimental investigation. J. Sustain. Cem. Mater. 2016, 5, 24. [CrossRef]

98. Dybeł, P.; Furtak, K. Assessment of the Casting Position Factor in Reinforced Concrete Elements in View of Experimental Studies. Arch. Civ. Eng. 2014, 60, 209-222. [CrossRef]

99. Lameiras, R.; Barros, J.A.; Azenha, M. Influence of casting condition on the anisotropy of the fracture properties of Steel Fibre Reinforced Self-Compacting Concrete (SFRSCC). Cem. Concr. Compos. 2015, 59, 60-76. [CrossRef]

100. Chin, M.S.; Mansur, M.A.; Wee, T.H. Effects of shape, size, and casting direction of specimens on stress-strain curves of high-strength concrete. Mater. J. 1997, 94, 209-219.

101. Grdic, Z.J.; Curcic, G.A.T.; Ristic, N.S.; Despotovic, I.M. Abrasion resistance of concrete micro-reinforced with polypropylene fibers. Constr. Build. Mater. 2012, 27, 305-312. [CrossRef]

102. Gencel, O.; Gok, M.S.; Brostow, W. Effect of metallic aggregate and cement content on abrasion resistance behaviour of concrete. Mater. Res. Innov. 2011, 15, 116-123. [CrossRef]

103. Liu, Y.-W. Improving the abrasion resistance of hydraulic-concrete containing surface crack by adding silica fume. Constr. Build. Mater. 2007, 21, 972-977. [CrossRef]

104. Felekoğlu, B.; Türkel, S.; Altuntaş, Y. Effects of steel fiber reinforcement on surface wear resistance of self-compacting repair mortars. Cem. Concr. Compos. 2007, 29, 391-396. [CrossRef]

105. Onuaguluchi, O.; Eren, Ö. Recycling of copper tailings as an additive in cement mortars. Constr. Build. Mater. 2012, 37, 723-727. [CrossRef]

106. García, A.; Castro-Fresno, D.; Polanco, J.A.; Thomas, C. Abrasive wear evolution in concrete pavements. Road Mater. Pavement Des. 2012, 13, 534-548. [CrossRef]

107. García, Á.; Fresno, D.C.; Polanco, J.A. Effect of dry-shaking treatment on concrete pavement properties. Constr. Build. Mater. 2008, 22, 2202-2211. [CrossRef]

108. He, Z.; Chen, X.; Cai, X. Influence and mechanism of micro/nano-mineral admixtures on the abrasion resistance of concrete. Constr. Build. Mater. 2019, 197,91-98. [CrossRef]

109. Haruehansapong, S.; Pulngern, T.; Chucheepsakul, S. Effect of Nanosilica Particle Size on the Water Permeability, Abrasion Resistance, Drying Shrinkage, and Repair Work Properties of Cement Mortar Containing Nano-SiO. Adv. Mater. Sci. Eng. 2017, 2017, 1-11. [CrossRef]

110. Siddique, R. Effect of fine aggregate replacement with Class F fly ash on the abrasion resistance of concrete. Cem. Concr. Res. 2003, 33, 1877-1881. [CrossRef]

111. Silva, C.V.; Zorzi, J.E.; Cruz, R.C.; Molin, D.C.D. Experimental evidence that micro and macrostructural surface properties markedly influence on abrasion resistance of concretes. Wear 2019, 422, 191-200. [CrossRef]

112. Al-Kheetan, M.J.; Rahman, M.M. Integration of Anhydrous Sodium Acetate (ASAc) into Concrete Pavement for Protection against Harmful Impact of Deicing Salt. JOM 2019, 1-11. [CrossRef]

113. Popek, M.; Sadowski, Ł.; Szymanowski, J. Abrasion Resistance of Concrete Containing Selected Mineral Powders. Procedia Eng. 2016, 153, 617-622. [CrossRef]

114. Niewiadomski, P.; Stefaniuk, D. The Effect of Adding Selected Nanoparticles on the Mechanical Properties of the Cement Matrix of Self-Compacting Concrete. Appl. Mech. Mater. 2015, 797, 158-165. [CrossRef]

115. Krakowiak, K.J.; Thomas, J.J.; James, S.; Abuhaikal, M.; Ulm, F.-J. Development of silica-enriched cement-based materials with improved aging resistance for application in high-temperature environments. Cem. Concr. Res. 2018, 105, 91-110. [CrossRef]

116. Diamanti, M.V.; Paolini, R.; Rossini, M.; Aslan, A.B.; Zinzi, M.; Poli, T.; Pedeferri, M.P. Long term self-cleaning and photocatalytic performance of anatase added mortars exposed to the urban environment. Constr. Build. Mater. 2015, 96, 270-278. [CrossRef] 
117. Mohammed, A.; Sanjayan, J.G.; Duan, W.H.; Nazari, A. Graphene Oxide Impact on Hardened Cement Expressed in Enhanced Freeze-Thaw Resistance. J. Mater. Civ. Eng. 2016, 28, 4016072. [CrossRef]

118. Behfarnia, K.; Salemi, N. The effects of nano-silica and nano-alumina on frost resistance of normal concrete. Constr. Build. Mater. 2013, 48, 580-584. [CrossRef]

119. Beeldens, A. An environmental friendly solution for air purification and self-cleaning effect: the application of $\mathrm{TiO}_{2}$ as photocatalyst in concrete. In Proceedings of the Transport Research Arena Europe-TRA, Göteborg, Sweden, 12-15 June 2006; pp. 12-16.

120. Sebök, T.; Stráněl, O. Wear resistance of polymer-impregnated mortars and concrete. Cem. Concr. Res. 2004, 34, 1853-1858. [CrossRef]

121. Christodoulou, C.; Goodier, C.; Austin, S.; Webb, J.; Glass, G.; Goodier, C. Long-term performance of surface impregnation of reinforced concrete structures with silane. Constr. Build. Mater. 2013, 48, 708-716. [CrossRef]

122. Pigino, B.; Leemann, A.; Franzoni, E.; Lura, P. Ethyl silicate for surface treatment of concrete-Part II: Characteristics and performance. Cem. Concr. Compos. 2012, 34, 313-321. [CrossRef]

123. Franzoni, E.; Varum, H.; Natali, M.E.; Bignozzi, M.C.; Melo, J.; Rocha, L.; Pereira, E. Improvement of historic reinforced concrete/mortars by impregnation and electrochemical methods. Cem. Concr. Compos. 2014, 49, 50-58. [CrossRef]

124. Almusallam, A.; Khan, F.; Dulaijan, S.; Al-Amoudi, O. Effectiveness of surface coatings in improving concrete durability. Cem. Concr. Compos. 2003, 25, 473-481. [CrossRef]

125. Delucchi, M.; Barbucci, A.; Cerisola, G. Study of the physico-chemical properties oforganic coatings for concrete degradation control. Constr. Build. Mater. 1997, 11, 365-371. [CrossRef]

126. Diamanti, M.V.; Brenna, A.; Bolzoni, F.M.; Berra, M.; Pastore, T.; Ormellese, M. Effect of polymer modified cementitious coatings on water and chloride permeability in concrete. Constr. Build. Mater. 2013, 49, 720-728. [CrossRef]

127. Choudalakis, G.; Gotsis, A. Permeability of polymer/clay nanocomposites: A review. Eur. Polym. J. 2009, 45, 967-984. [CrossRef]

128. Moon, H.Y.; Shin, D.G.; Choi, D.S. Evaluation of the durability of mortar and concrete applied with inorganic coating material and surface treatment system. Constr. Build. Mater. 2007, 21, 362-369. [CrossRef]

129. Pan, X.; Shi, Z.; Shi, C.; Ling, T.-C.; Li, N. A review on concrete surface treatment Part I: Types and mechanisms. Constr. Build. Mater. 2017, 132, 578-590. [CrossRef]

130. Silva, J.J.; Ismael, R.; Carmo, R.N.F.; Lourenço, C.; Soldado, E.; Costa, H.; Júlio, E. Influence of nano-SiO 2 and nano- $\mathrm{Al}_{2} \mathrm{O}_{3}$ additions on the shear strength and the bending moment capacity of RC beams. Constr. Build. Mater. 2016, 123, 35-46. [CrossRef]

131. Ghazy, A.; Bassuoni, M.T. Shrinkage of Nano-modified Fly Ash Concrete as a Repair Material. ACI Mater. J. 2017, 114, 877-888. [CrossRef]

(C) 2019 by the author. Licensee MDPI, Basel, Switzerland. This article is an open access article distributed under the terms and conditions of the Creative Commons Attribution (CC BY) license (http://creativecommons.org/licenses/by/4.0/). 